\title{
Reunited after 1000 years. The development of definite articles in Icelandic
}

\section{Alexander Pfaff}

This article traces the diachronic development from the Proto Norse demonstrative hinn via the Old Icelandic definite article(s) to the Modern Icelandic article system. This demonstrative gave rise to two distinct article elements during the Viking period that are well-attested from Old Icelandic onwards, a freestanding and a suffixed article.

Based on evidence from Old Icelandic, I argue for a categorial distinction between an adjectival and a nominal article, which does not entirely coincide with a mere morphophonological distinction. The former, which mostly occurs as a freestanding element, is a genuine component of AP, not an immediate constituent of the nominal extended projection. The latter, which only occurs in suffixal form, heads a low projection in the extended nominal projection and has scope only over the noun. For Modern Icelandic, on the other hand, I will adopt the idea that free and suffixed articles are two surface manifestations of the same element.

The diachronic perspective is complemented by an examination of the development of seven adjectivally modified definite noun phrase patterns. This empirical survey reveals several surprising facts: The standard pattern of modification in Modern Icelandic was virtually non-existent prior to the $17^{\text {th }}$ century, and double definiteness persisted until the early $20^{\text {th }}$ century. Likewise, certain modificational patterns otherwise found in Mainland Scandinavian were dominant between the $16^{\text {th }}$ and $19^{\text {th }}$ century. This latter observation points to a competition between two adjectival articles hinn vs. sá similar to the one that had taken place earlier in Mainland Scandinavian. In Icelandic, however, sá did not replace hinn, and, in the long run, a pattern not comprising an adjectival article became the dominant one.

Keywords Icelandic, diachronic syntax, definiteness marking, double definiteness, adjectival modification, adjectival inflection, adjectival article, nominal article, competition

Alexander Pfaff, Department of Literature, Area Studies and European Languages, University of Oslo, POB 1003, Blindern,0315 OSLO, Norway. a.p.pfaff@ilos.uio.no

\section{INTRODUCTION}

The development of a demonstrative into a definite article is a well-known diachronic change. However, as the discussion in this article will show, the development from the Proto Norse demonstrative hinn towards the Modern Icelandic article system is a rather convoluted process, and interestingly different from the development in the other Scandinavian languages.

To begin with, in the modern Scandinavian languages, simple definiteness marking is expressed with the so-called suffixed article (DEF): ${ }^{1}$ 
(1) a. bil -en (Danish/Swedish/Norwegian)

car -DEF

b. bilur -in (Faroese)

car -DEF

c. bíll -inn (Icelandic)

car -DEF

In the context of adjectival modification, we find another definiteness marker:

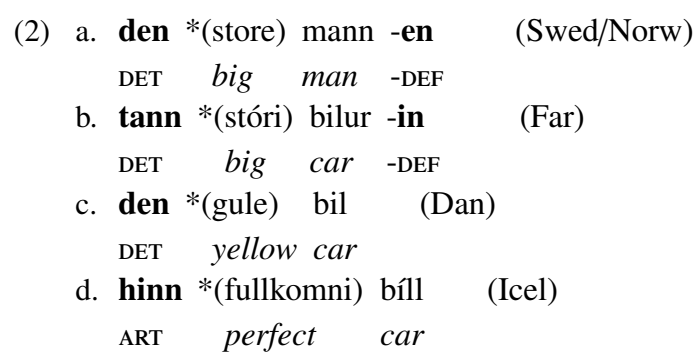

As indicated, the occurrence of this prenominal freestanding element is dependent on the presence of an adjective (this does not apply to demonstrative interpretation, see below), therefore it is often referred to as "adjectival article". I will maintain this terminology descriptively, but also give a bit more substance to it. While the adjectival articles in (2) are determiner elements, in Sect. 4, I will propose that the Old Icelandic adjectival article is a part of AP, not of the nominal projection (xNP). ${ }^{2}$

In Swedish, Norwegian and Faroese, the adjectival article cooccurs with the suffixed article, a phenomenon known as double definiteness. In Danish and Icelandic, on the other hand, the two cannot cooccur. There is, however, another demarcation line, which places Danish with the former group: the adjectival article in that group (DET) etymologically derives from (the accusative forms of) the distal demonstrative $s a^{3}{ }^{3}$ whereas the Icelandic adjectival article (ART) derives from the Proto Norse demonstrative hinn; see Sect. 1.2. Based on this criterion, I will employ a distinction between Icelandic and Non-Icelandic Scandinavian languages (= NIScan).

The demonstrative use of hinn (in the meaning "the other one") has survived into Modern Icelandic. Formally, it can be distinguished from the free article by the endings in the NOM/ACC.NEUT.SG: the demonstrative has hitt, the article has hið. Moreover, they differ in three further respects: (i) the article, but not the demonstrative, requires the presence of an adjective, (ii) the demonstrative requires a definite noun, the article disallows it, (iii) the demonstrative bears stress and can occur on its own:
(3) i. hitt (stóra) verk -ið
DEM big work -DEF
ii hitt (stóra) verk *(-ið)
(4) i hið *(stóra) verk
ART big work
DEM big work -DEF
ii hið stóra verk (*-ið)
ART big work -DEF
iii hitt (stóra verk -ið)
iii hið*(stóra verk)
DEM big work -DEF
ART big work

In the NIScan languages, hinn in article function has largely disappeared save 
for some fixed expressions (e.g. Swed.: hin håle/hin onde 'the evil (one)' = 'the devil'). Moreover, in Faroese and in some Norwegian varieties, it is still used with the demonstrative meaning "the other". Conversely, in the NIScan languages, the Old Norse distal demonstrative sá lives on not only as adjectival article ( $\rightarrow$ DET), but also as demonstrative, and points (i) and (iii) just pointed out for hinn also apply here. Thus examples (2-a)-(2-c) are actually fine without an adjective - with a demonstrative interpretation (typically with a stress on DET). These demonstrative interpretations of hinn and DET will be of no concern for the present article. The status of sá in the history of Icelandic, on the other hand, will be addressed and examined here in some detail.

In this article, I will examine the development of adjectivally modified definite noun phrases in Icelandic with a focus on the definiteness markers ("articles") involved. At a particular level of detail, I will trace the history of ART and DEF examining critical stages in Proto Norse, Old Icelandic ${ }^{4}$ and Modern Icelandic (henceforth PN, OI and MI), and propose the following critical steps/stages:

(0) The PN demonstrative hinn is reanalyzed as an adjectival article, an element of the adjectival constituent, during the Viking period. This construal is maintained at least throughout the OI period. (1) At some point, the reduced form inn may cliticize to a preceding noun and form a prosodic unit with it. (2) At some point, this prosodic unit gives rise to a morphosyntactic construal bringing about a novel element: a nominal article, which occupies a head position low in the nominal projection $\left(n^{0}\right)$. (3) By the beginning of the OI period, there are two categorially and structurally distinct article elements: an adjectival and a nominal article, where the former mostly occurs as freestanding element (ART), and the latter exclusively as bound element (DEF). (4) For MI, I will adopt the view that ART and DEF are two surface manifestations of the same underlying element occupying one designated position high in the nominal projection (above adjectives).

The bulk of the discussion focuses primarily on (0-3), i.e. establishing that there are two categorially distinct article elements in OI, rather than on the developments that lead from (3) to (4). Due to the large empirical coverage and for methodological reasons, there are some further limitations. In some cases, I will ignore certain specific technical details, remaining at a pretheoretical or descriptive (semi-formal) level. Likewise, the focus here is on definiteness marking; I will not address semantic aspects of definiteness.

The remainder of this section addresses a number of methodological issues and introduces the patterns to be examined here. Moreover, the development from PN to OI and some analytical perspectives on the definite article in Old Norse will be discussed. In Sect. 2, I will take a look at the article system in MI adopting a one-article analysis according to which ART and DEF are two manifestations of the same article element at some abstract level of analysis. Sect. 3 presents a diachronic perspective and examines the develoment of the various patterns from OI to MI. In Sect. 4, I will present arguments in favor of analyzing the freestanding pre-adjectival article ART as an element of AP in OI, not as a determiner in xNP. Sect. 5 argues for the 
emergence of a distinct nominal article as a result of a morpho-syntactic reanalysis of a constellation where the element $(h)$ inn forms a prosodic unit with a preceding noun. Sect. 6 addresses some diachronic implications of the points made in Sects. 2-5. Sect. 7 concludes the discussion.

\subsection{Some methodological remarks}

\subsubsection{The historical data - some caveats}

For the historical survey, I will largely be drawing on examples and numbers from the Icelandic Parsed Historical Corpus (IcePaHC), ${ }^{5}$ which contains 1.002 .390 word tokens from the $12^{\text {th }}$ to the $21^{\text {st }}$ century. Specifically, I will use the numbers produced by IcePaHC queries as basis for calculating proportions. The numbers given will represent occurrences per century (rather than per text) - with one exception: the texts from the $20^{\text {th }}$ and $21^{\text {st }}$ centuries have been conflated (represented as " $20 »$ ”). It should be acknowledged that there are some individual cases of misannotation. ${ }^{6}$ While the examples actually used here have all been checked and can be considered genuine, there is a slight possibility that one or another example may have been

missed. We must furthermore keep in mind that the selection of text samples in IcePaHC may not be entirely balanced, and for certain periods, there may be a genre bias. Also the selection of text samples, at least in some cases, may not necessarily reflect the language of the native Icelandic population at large. This is particularly relevant when discussing potential Danish influence (see fn. 27), which, in all likelyhood, was greater amongst those (authors) who actually spoke Danish.

I will also provide some additional data from Mörkuð Íslensk Málheild (MÍM) ${ }^{7}$ in order to give a more nuanced picture for Old Icelandic. The collection of Old Icelandic texts (fornrit) in MÍM comprises 1.659.385 word tokens from the Saga literature (roughly covering the $13^{\text {th }} / 14^{\text {th }}$ centuries). A comparison of the token numbers shows that MÍM contains vastly more material for that period than IcePaHC. ${ }^{8}$ However, the tokens in MÍM are automatically annotated, and many tokens are misannotated (e.g. adjectives as nouns, verbs as adjectives etc.). Therefore, a specific query may not yield all instances of the respective pattern actually contained in the database, and vice versa, not all results produced are actually instances of the queried pattern. I have manually reviewed and filtered the outputs of MíM queries (so as to only use and count genuine examples), but since it is not clear how many relevant examples have not been captured in the first place, those numbers have to be understood as an existential statement: there are at least $n$ instances of a query pattern $X$ in the MÍM database. Nonetheless, it will turn out that the results from MÍM queries do, broadly speaking, support the findings from the IcePaHC queries.

The Runic data (incl. signatures) are from Samnordisk Rundatabas, ${ }^{9}$ from which I also adopt periodization (Proto Norse, Viking period) and normalizations.

\subsubsection{Adjectivally modified noun phrase patterns}

I will almost exclusively be looking at adjectivally modified definite noun phrases. Naturally, this only constitutes a small subset of all noun phrases. To give a rough 
idea of the dimensions, consider this: table 1 gives the raw numbers of occurrences per century of noun phrases comprising a lexical noun (noun) - as opposed to a proper name or a zero noun - and occurrences of such noun phrases comprising, in addition, at least one attributive adjective (adj), (at least) a freestanding article (ART), (at least) a suffixed article (DEF), or (at least) a distal demonstrative (sá). ${ }^{10}$ Table 2 gives the corresponding proportions relative to the total of lexical noun phrases:

Table 1. Lexical noun phrases: basic numbers in absolute terms (based on IcePaHC)

\begin{tabular}{||l||c||r|r|r|r||}
\hline \hline & $\begin{array}{c}\text { noun } \\
\text { =total (of lexical noun phrases) }\end{array}$ & adj & ART & DEF & sá \\
\hline \hline $\mathbf{1 2}^{\text {th }}$ & 7094 & 938 & 143 & 475 & 360 \\
\hline $\mathbf{1 3}^{\text {th }}$ & 17333 & 1393 & 251 & 2702 & 1012 \\
\hline $\mathbf{1 4}^{\text {th }}$ & 15519 & 1405 & 266 & 2030 & 763 \\
\hline $\mathbf{1 5}^{\text {th }}$ & 13382 & 1196 & 146 & 2443 & 517 \\
\hline $\mathbf{1 6}^{\text {th }}$ & 10859 & 1369 & 74 & 2175 & 561 \\
\hline $\mathbf{1 7}^{\text {th }}$ & 18288 & 2387 & 64 & 3623 & 1016 \\
\hline $\mathbf{1 8}^{\text {th }}$ & 15692 & 2236 & 161 & 2728 & 704 \\
\hline $\mathbf{1 9}^{\text {th }}$ & 16597 & 2065 & 163 & 4301 & 473 \\
\hline $\mathbf{2 0}^{\text {20 }}$ & 24076 & 3495 & 157 & 7561 & 563 \\
\hline \hline total: & 138840 & 16484 & 1425 & 28038 & 5969 \\
\hline \hline
\end{tabular}

Table 2. Lexical noun phrases: basic numbers in percentage (based on IcePaHC)

\begin{tabular}{||l||r|r|r|r||}
\hline \hline & adj & ART & DEF & sá \\
\hline \hline $\mathbf{1 2}^{\text {th }}$ & 13.2 & 2.0 & 6.7 & 5.1 \\
\hline $\mathbf{1 3}^{\text {th }}$ & 8.0 & 1.4 & 15.6 & 5.8 \\
\hline $\mathbf{1 4}^{\text {th }}$ & 9.1 & 1.7 & 13.1 & 4.9 \\
\hline $\mathbf{1 5}^{\text {th }}$ & 8.9 & 1.1 & 18.3 & 3.9 \\
\hline $\mathbf{1 6}^{\text {th }}$ & 12.6 & 0.7 & 20.0 & 5.2 \\
\hline $\mathbf{1 7}^{\text {th }}$ & 13.1 & 0.3 & 19.8 & 5.6 \\
\hline $\mathbf{1 8}^{\text {th }}$ & 14.2 & 1.0 & 17.4 & 4.5 \\
\hline $\mathbf{1 9}^{\text {th }}$ & 12.4 & 1.0 & 25.9 & 2.8 \\
\hline $\mathbf{2 0}^{\text {» }}$ & 14.5 & 0.7 & 31.4 & 2.3 \\
\hline
\end{tabular}

Considering, furthermore, that the set of relevant noun phrases arises from an intersection of adj and at least one of the other types, it follows that that set is actually rather small. As we will see, in several cases, attestations per century amount to mere one-digit numbers, which means that even minor imprecisions in the input data can lead to noticeable effects on the proportion scale. Therefore, the numbers presented here should be approached with caution, and a fluctuation of $+/-$ some percentage points should not be overrated. Conclusions drawn here based on these numbers may need to be refined or modified once larger text samples are examined.

Below, I give an overview of the patterns relevant for the discussion to come using a "dummy" example (the yellow horse; definiteness markers and other characteristic properties like inflection and postposition in boldprint): 
6

ALEXANDER PFAFF

(5) a. A.wK N-DEF

guli hestur-inn

(I)

yellow.wK horse-DEF

b. ART A.wK N

hinn guli hestur

(II)

ART yellow.wK horse

c. N-DEF A.wK

hestur-inn guli

horse-DEF yellow.wK

d. A.str N-Def

gulur hestur-inn

yellow.STR horse-DEF

e. aRT A.wK N-DEF

hinn guli hestur-inn

ART yellow.wK horse-DEF

f. Sá A.wK N-DEF

sá guli hestur-inn

sÁ yellow.WK horse-DEF

g. Sá A.wK N

sá guli hestur

sá yellow.wK horse

(III)

DD-a

The labels for patterns (I)-(IV) are adopted from Pfaff $(2014,2015)$, see Sect. 2. Pattern (I) is the standard or default pattern of adjectival modification in definite noun phrases in MI, and by far the most frequent one; the other three have more specialized uses and hence a more limited occurrence. ${ }^{11}$ In this purely statistical sense, they are marked patterns (as a mere convention, I will refer to a pattern as marked here if its proportion is below 20\%).

In certain contexts, I will furthermore distinguish two varieties of pattern (III), one of which involves a postnominal freestanding article (ART instead of DEF):

(6) a. N-DEF A.wK

(III-a) hestur-inn guli

horse-DEF yellow.wK

b. N arT A.wK

hestur hinn guli

horse ART yellow.wK

(III-b)

I will distinguish two varieties of double definiteness, neither of which is wellformed in MI: DD-a, which involves the co-occurrence of ART and DEF, (7-a), and DD-b, which has the distal demonstrative sá instead of ART (and etymologically corresponds to the double definiteness pattern found in NIScan (2-a)/(2-b)), (7-b):

(7) a. *hið fræga verk -ið (Sigurðsson 1993)

ART famous work -DEF

b. *sú gamla kona -n (Thráinsson 2007, 113)

sá old woman -DEF

DAN - the constellation etymologically corresponding to the Danish pattern, cf. (2-c) 


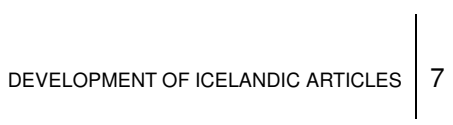

- is fine in MI, but typically it conveys more than simple definiteness by adding a demonstrative or emphatic component.

It should be noted that this is not an exhaustive set of possible patterns found in (the history of) the Icelandic noun phrase, but for practical reasons, I will limit my focus to these seven. A "pattern", as the term will be used here, refers to a surface string defined by a number of formal properties (free vs. suffixed article; pre- vs. postnominal adjective etc.). Patterns do not have any theoretical status, and we will see that identical surface patterns may have different underlying structures. Rather they are a methodological device providing a constant standard for comparison and allowing us to quantify diversity/variation and make visible develoments that otherwise go unnoticed when only individual elements are examined (see Sect. 3).

\subsection{Prologue: From Proto Norse to Old Icelandic}

The PN pronominal element $h$-inn can be reconstructed as a fusion of two deictic/pronominal stems PIE *ke + *eno- (Pokorny 1959; see also Skrzypek 2009; Stroh-Wollin 2014). In the "Proto Norse" period (prior to ca. 725), it is attested as a demonstrative, (8-a). From the "Viking Period" (ca. 725 - 1100) onwards, hinn, or an $h$-less variant inn, assumes the function of adjectival article, consistently occurring in the sequence $(h) i n n+A d j$. In the vast majority of cases, it occurs with a proper name (acting as some kind of epithet), (8-b)/(8-c):

(8) a. hali hino (N KJ50 \$U)
stone this
b. in heilhi kristr (Sö 125)
the holy Christ
c. kuna harats hins kupa (DR 55)
wife (of) Haraldr the good
When immediately following a lexical noun, at some point
prosodic word with the preceding noun as evidenced by by
(9) (Sö 41; mirkit*mikla* ${ }^{\text {th }}$ century)
merki it mikla (normalized text)
monument the great

The distinction lexical noun vs. proper name has largely remained relevant also in the long run since the suffixed article usually only occurs on the former - with the occasional exception (see the final paragraph in Sect. 5.2):

(10) Eirikinum hælghae

(Börjars and Harries 2008, 297) Erik.the holy

So in (9) and (10), (h)inn forms a prosodic constituent with the preceding noun; but, as in (8-b)/(8-c), it also forms a syntactic unit with the adjective. At some point, we find attestations of $(h)$ inn solely associating with the preceding noun without an adjective. The following example is usually considered the earliest attested instance of what has become the suffixed article in the Scandinavian languages: ${ }^{13}$ 
(11) kup hialbi antini (U $669 \dagger$; late $11^{\text {th }}$ century)

god help.suBJ soul.the (= 'may god help the soul')

At face value, these various stages can be schematically represented as follows:
(12) A. $\quad \mathrm{N}$ hinn
B. $\Rightarrow \mathrm{N}(\mathrm{h})$ inn $\mathrm{A}$
C. $\Rightarrow \mathrm{N}$-inn $\mathrm{A}$
D. $\Rightarrow \quad \mathrm{N}$-inn
hinn $=$ demonstrative
(h)inn $=\mathrm{ART}$
$-i n n=\mathrm{DEF}$
$-i n n=\mathrm{DEF}$

One interpretation of (12) is that the demonstrative gives rise to the adjectival article which, in turn, gives rise to the suffixed article; i.e. DEF is an immediate "offspring" of ART. This reconstruction was first proposed by Delbrück (1916) and is the basis for the analysis e.g. in Roehrs and Sapp (2004), but it is not uncontroversial. One prominent argument against this reconstruction is statistical in nature: the postnominal adjectival article mostly occurs whith proper names in an epithetic function (see above), and is thus an unlikely source for a definiteness marker that occurs on lexical nouns. As an alternative, it has been suggested that it is the demonstrative itself occurring in postposition that gives rise to the suffixed article (Nygaard 1906; Skrzypek 2009, 2010, 2012; Stroh-Wollin 2009, 2014, 2015a,b, 2016; Perridon and Sleeman 2011; Dahl 2015). A simple way of representing this latter idea is the following:

$$
\begin{array}{lllll} 
& \Rightarrow & (h) \text { inn } & \text { (ART) } \\
\text { hinn (demonstrative) } & & & \\
& \Rightarrow & -i n n & \text { (DEF) }
\end{array}
$$

I will not take a definite stance on this issue here. What is relevant for the discussion to come is the observation that, by the beginning of the OI period, we find two distinct article elements that had emerged during the Viking period. Whether DEF really developed directly from ART, or whether both merely have a common ancestor is of secondary importance (but see Sects. 5.1 and 5.2 where the issue is framed somewhat differently).

Another relevant observation is that examples (8-b), (8-c) and (9) illustrate that what are referred to here as patterns (II) and (III-b)/(III-a) are attested during the Viking period. Patterns (I) and DD-a, on the other hand, do not seem to be attested before the OI period.

\subsection{Analytical aspects: The definite article in Old Icelandic}

Already in the earliest OI text, both the freestanding adjectival article ART and the suffixed article DEF are well attested in various constellations:
(14) a. maðr -inn
man -DEF
b. maðr -inn gamli
man -DEF old
c. maðr (h)inn gamli
man ART old
d. (h)inn gamli maðr
ART old man

Many analyses treat both as definite articles, and thereby make two claims that I will contest: (i) there is one definite article, and this one definite article can occur ei- 
ther as a free form (ART) or as a bound form (DEF), and (ii) this definite article is a genuine determiner that occupies some immediate position in the extended nominal projection (xNP), either a high position above adjectives (Faarlund 2004, 2007, 2009; Lohndal 2007; Laake 2007) or a low position below adjectives (Roehrs and Sapp 2004).

Regarding the development from Old Norse to Modern Norwegian, Lohndal (2007); Faarlund (2009) argue in favour of "grammaticalization down the tree" along the grammaticalization cline cLITIC > AFFIx: the definite article is reanalyzed from a clitic occupying a high position to an affix occupying a low position. Lohndal argues that this low position is $\mathrm{n}^{0}$, which emerges during the latter part of the Old Norse period alongside double definiteness (see also Sect. 3.1.3). As a clitic, the article element can occur as ART or DEF, but once analysed as an affix, only as DEF (cf. Sect. 6.2). Meanwhile, the free form (ART) disappears in Norwegian with its function gradually being taken over by the demonstrative $s a ́$ ( $\rightarrow$ DET).

Prima facie, (i) and (ii) are reasonable assumptions given alternations like (14-b) vs. (14-c) (= patterns (III-a) vs. (III-b)), and the observation that DEF and ART are identical in stem and inflection. In fact, I will propose an analysis in this vein for MI, see Sect. 2.1. There are some problems, however, not least that these assumptions are closely linked to a reconstruction that, as was mentioned in the previous subsection, is not uncontroversial.

One alternative approach to the adjectival article ART assumes that it is actually an element of the adjectival constituent (for instance Nygaard 1906; Lundeby 1965; Perridon 1996; Skrzypek 2009, 2010; Perridon and Sleeman 2011; Stroh-Wollin 2009, 2015a; Börjars and Payne 2016; Börjars et al. 2016; "Gelenkartikel" in Heinrichs 1954; Himmelmann 1997, and "attributive article" in Rießler 2016).

I will follow this latter idea and propose that ART is not an immediate constituent of the nominal projection in OI, but of AP (Sect. 4). Consequently, I will also argue that ART and DEF are potentially distinct elements. I will argue for a nominal article (Sect. 5) and suggest that, similarly to Lohndal's analysis, a certain reanalysis of the suffixed article did bring about a new low $\mathrm{n}^{0}$ position, but at an earlier time, and in a different fashion.

\section{Point of departure - Modern Icelandic}

As already mentioned, MI has - descriptively speaking - two definite articles (ART and DEF), which cannot cooccur. In simple modified definite noun phrases comprising the elements \{ ARTICLE, ADJECTIVE, NOUN\}, we potentially find four different surface patterns (cf. Pfaff 2014, 2015), namely patterns (I)-(IV) introduced in (5). In this section, I will address two aspects that have some bearing on an assessment of the diachronic developments to be discussed in the following sections.

\subsection{The one-article analysis}

It is widely assumed that there is one definite article in MI, viz. (h)inn, with ART and DEF being two surface variants (Magnússon 1984; Sigurðsson 1993; Pfaff 2007, 
$10 \mid$ ALEXANDER PFAFF

2009, 2014, 2015; Harðarson 2016; Ingason 2016). ${ }^{14}$ The two major (synchronic) motivations for this assumption are

i. complementary distribution (recall that DD-a is ungrammatical in MI, (7-a)),

ii. identity of stem and inflection in both elements (the central difference is the presence/absence of ' $h$ ': $\underline{\text { hinn }}$ vs. -inn; see fn. 15)

A movement analysis of the article was first proposed by Magnússon (1984), modified by Sigurðsson (1993). The gist of the analysis is that the sequence ARTICLE - A - N can surface as such, in which case the article is realized as ART (= pattern (II)), or a constituent containing $\mathrm{A}$ and $\mathrm{N}$ moves before the article as a result of which the article cliticizes onto the noun and is realized as DEF (= pattern (I)): ${ }^{15}$

$$
\begin{array}{lll}
{[\operatorname{ARTICLE}[\mathrm{A} \mathrm{N}]]} & \Rightarrow & {[\text { ART [A N] ] }} \\
& \Rightarrow & {[[\mathrm{A} \mathrm{N}]-\mathrm{DEF}[\mathrm{AN}]}
\end{array}
$$

For the purpose of this article, I will adopt this idea; in the following, I will summarize an additional argument developed in Pfaff $(2015,29-48,91-115)$ that relates position and interpretation of the adjective involved. One initial observation is that there seem to be semantic differences between the two articles. ${ }^{16}$ Sometimes, pattern (I) is bad, seemingly for semantic reasons, and pattern (II) has to be used instead:

(16) a. *svokallaða afstæðiskenning -in so-called.wK theory-of-relativity -DEF

b. hin svokallaða afstæðiskenning ART so-called.WK theory-of-relativity

(17) (Thráinsson 2007:89, fn. 2)

a. *pekkti leikari -nn Clint Eastwood known.wK actor -DEF Clint Eastwood

b. hinn pekkti leikari Clint Eastwood ART known.wK actor Clint Eastwood
(I)

Prima facie, this could mean that DEF - but not ART - is incompatible with certain adjectives or adjectival meanings, and hence, that the two articles are not semantically equivalent (and by extension, that they are two distinct lexical items). Upon closer inspection, however, these examples do not illustrate a contrast between the two article elements per se. This becomes clear when we take into account that the corresponding pattern (III) versions are fine:
a. afstæðiskenning -in svokallaða theory-of-relativity -DEF so-called.wK
b. leikari -nn pekkti Clint Eastwood actor -DEF known.wK Clint Eastwood

Since pattern (III) does involve DEF, and since it is fine precisely in those contexts where pattern (II) is fine (with the same interpretation), it is evident that the real contrast observed above is not about ART Vs. DEF, but rather about patterns (II)/(III) vs. pattern (I). In particular, it is the adjective's position relative to the article (ART or 
DEF) that is relevant; what patterns (II) and (III) have in common is that the adjective immediately follows the article - regardless of whether free or suffixed:

(19) i. *svokallaða afstæðiskenning -in

ii. hin svokallaða afstæðiskenning

iii. afstæðiskenning -in svokallaða

This can be captured in terms of movement where patterns (I) and (III) differ in which constituent is fronted before the article. Conversely, what patterns (II) and (III) have in common is that the adjective remains in situ, in the post-article position: ${ }^{17}$

(20) a. $[$ ARTICLE $[\mathrm{A} \mathrm{N}]] \Rightarrow[$ ART $[\mathrm{A} \mathrm{N}]]$ :

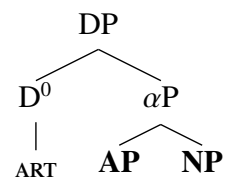

b. $\quad[$ ARTICLE $[\mathrm{A} \mathrm{N}]] \Rightarrow[\mathrm{N}-\mathrm{DEF}[\mathrm{A} N]]$ :

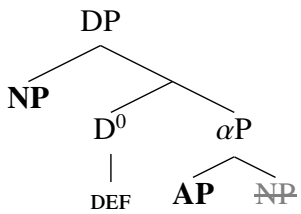

c. $[\operatorname{ArTicle}[\mathrm{A} \mathrm{N}]] \Rightarrow[[\mathrm{A} \mathrm{N}]-\operatorname{Def}[\AA \mathrm{N}]]$ :

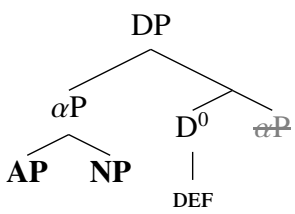

Notice that the crucial point is not about linear surface position, but about height in terms of structural position. Following the logic of this analysis, if two adjectives are present, the lower one is expected to move along with the noun to a pre-article position, while the higher one is stranded:

(21) a. [ARTICLE $\left.\left[\mathrm{A}_{1} \mathrm{~A}_{2} \mathrm{~N}\right]\right]$

b. [ARTicle $\left.\left[\mathrm{A}_{1} \mathrm{~A}_{2} \mathrm{~N}\right]\right]$

$\Rightarrow$

$\Rightarrow$
[ ART $\left.\left[\mathrm{A}_{1} \mathrm{~A}_{2} \mathrm{~N}\right]\right]$

$\left[\left[\mathrm{A}_{2} \mathrm{~N}\right]-\mathrm{DEF}\left[\mathrm{A}_{1}\left[\mathrm{~A}_{2} \mathrm{~N}\right]\right]\right]$

According to (21), the postnominal adjective in a "mixed" pattern (I+III) is merged in a higher position than the prenominal one. Thus a well-formed mixed pattern should display the reverse surface order of adjectives in the corresponding pattern (II) version, and in particular, the postnominal adjective $\left(\mathrm{A}_{1}\right)$ is expected to have scope over the prenominal one $\left(\mathrm{A}_{2}\right)$. These expectations are borne out:
a. hið svokallaða kalda stríð ART so-called.wK cold.wK war SO-CALLED $>>$ COLD
b. kalda stríð -ið svokallaða cold.wK war -DEF so-called.wK SO-CALLED >> COLD

(II) 


$$
\begin{aligned}
& \text { c. *svokallaða stríð -ið kalda } \\
& \text { so-called.wK war -DEF cold.wK } \\
& \text { (cOLD >> so-cALLED) }
\end{aligned}
$$

(I+III)

It is, more generally, the case that only adjectives that are merged sufficiently high in the structure can surface in an immediate post-article position, i.e. in patterns (II)/(III). Pfaff (2015) makes the somewhat vague notion "sufficiently high" more precise and proposes a projection labeled ixP ("index phrase") such that adjectives can be merged inside $i x \mathrm{P}$ or outside/above ixP. In (23) below, both $\alpha \mathrm{P}$ and $\beta \mathrm{P}$ are functional projections hosting adjectives in their specifiers (cf. fn. 17), the crucial difference being their relative positions to ixP. Thus an adjective merged in Spec- $\alpha \mathrm{P}$ indicates an $i x \mathrm{P}-$ internal position, and and adjective merged in Spec- $\beta \mathrm{P}$ indicates an $i x \mathrm{P}$-external position. Now $i x \mathrm{P}$ is the relevant constituent that is affected by movement resulting in N-DEF (patterns (I)/(III)/(IV), but also unmodified definite nouns). Therefore, if movement takes place, ixP-external adjectives like "svokallaða" in (23-b) never move alongside the noun and thus always occur in the post-article position, see also (23-a). On the other hand, ixP-internal adjectives like "kalda" in (23-b) always move along (cf. Pfaff 2015, 119-127):

(23) a.

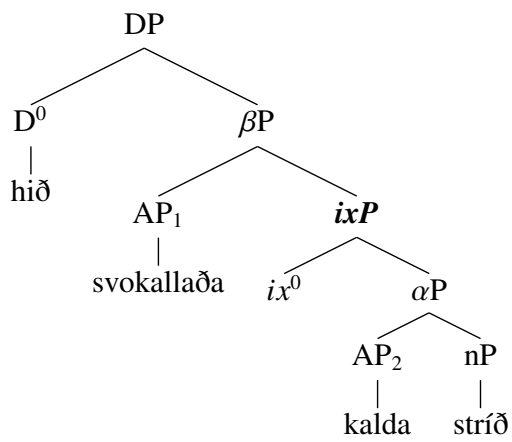

b.

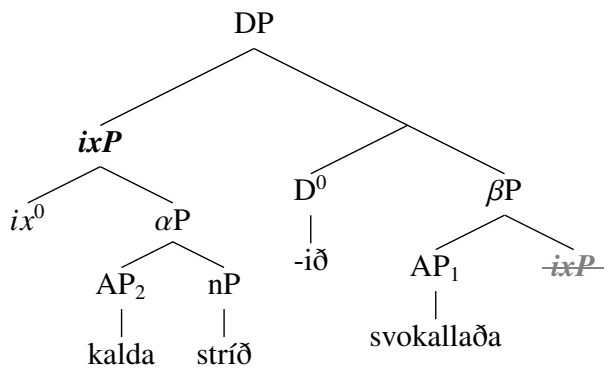

(I)+(III)

Being merged in that high position, in turn, has semantic effects. Put informally, the adjective provides some comment or evaluation on the referent denoted by the lower noun phrase; besides so-called, we typically find evaluative adjectives (famous, popular ...) in patterns (II)/(III). This is the source of the apparent semantic differences between articles, cf. (16)-(18), fn. 16. The relevant interpretation is determined by occurring in that high post-article position, not by the shape of the article.

Beyond this distinction between a higher and a lower domain for adjectives, 
all adjectives in patterns (I)-(III) have something in common: they occur in the weak inflection. On Pfaff's account, this is a consequence of the initial configuration prior to (potential) movement where a definiteness morpheme, namely the ARTICLE, c-commands all adjectives; weak inflection is a reflex of this configuration (see next subsection).

The assumption that ART and DEF are two manifestations of the same element merged in a position above adjectives, couched in an analysis along the lines of (20)/(21), captures, in an elegant and simple fashion, the commonalities of patterns (II) and (III), the ordering and scope relations in mixed patterns, and the weak adjectival inflection. Apparent semantic differences between the two articles, cf. (16)/(17) turn out to be epihenomal insofar as they arise as a corollary of the respective adjective being merged in a high position. If ART and DEF were two distinct elements and occupied distinct positions, these correlations would be a mere coincidence.

\subsection{Adjectival inflection}

In Scandinavian, weak adjectival inflection is typically associated with definiteness, whereas strong inflection is a default in the sense that it occurs elsewhere (indefinite noun phrases, predicative contexts). MI moreover provides the interesting case of pattern (IV), the hallmark of which is that - even though it represents the same surface string as pattern (I) - the modifier involved is strongly inflected.

Pfaff $(2015,2017)$ proposes that an adjective is weakly inflected if it is merged in a position c-commanded by a definiteness feature (contributed e.g. by the definite article). Given what was said about the common base position of patterns (I)-(III) in the previous subsection, it is therefore expected that the adjective in those patterns is weakly inflected. Obviously, this does not apply to pattern (IV). Pfaff argues that the reason for this is that pattern (IV) modifiers are merged in a higher position, outside the c-command domain of the definiteness feature as a result of which the weak inflection cannot be triggered, and the default strong inflection occurs: ${ }^{18}$

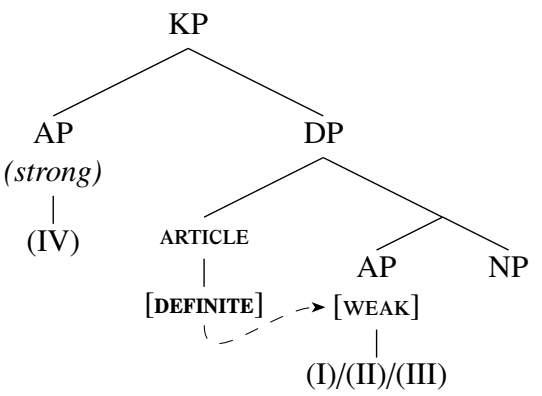

Pfaff $(2017,294)$

I will adopt (a version of) the idea that weakly inflected adjectives must be ccommanded by some definiteness morpheme, see Sect. 5.4 (also Sect. 4.1). 
14 ALEXANDER PFAFF

\section{From Old Icelandic to Modern Icelandic}

In this section, I will discuss the development of the patterns introduced in (5), and point out some observations of interest. In Sect. 3.1, I will focus on the patterns involving ART and/or DEF (i.e. patterns (I)-(IV) and DD-a), and in Sect. 3.2, I will add the patterns involving sá (i.e. DD-a and DAN).

The discussion is primarily based on the numbers in tables 3 and 4, which provide an overview of the relevant patterns in terms of occurrences per century (raw numbers and proportions; the numbers are based on IcePaHC queries):

Table 3. Patterns: occurrences per century in absolute terms (based on IcePaHC)

\begin{tabular}{||l||r|r|r|r|r|r|r||r||}
\hline \hline & (I) & (II) & (III) & (IV) & DD-a & DD-b & DAN & total: \\
\hline \hline $\mathbf{1 2}^{\text {th }}$ & 1 & 130 & 6 & 2 & 2 & 0 & 5 & 146 \\
\hline $\mathbf{1 3}^{\text {th }}$ & 4 & 174 & 16 & 18 & 9 & 0 & 23 & 244 \\
\hline $\mathbf{1 4}^{\text {th }}$ & 0 & 180 & 20 & 7 & 4 & 0 & 28 & 239 \\
\hline $\mathbf{1 5}^{\text {th }}$ & 3 & 106 & 16 & 11 & 14 & 0 & 28 & 178 \\
\hline $\mathbf{1 6}^{\text {th }}$ & 2 & 49 & 7 & 5 & 6 & 10 & 98 & 177 \\
\hline $\mathbf{1 7}^{\text {th }}$ & 30 & 30 & 17 & 11 & 5 & 43 & 195 & 331 \\
\hline $\mathbf{1 8}^{\text {th }}$ & 43 & 114 & 7 & 5 & 10 & 3 & 158 & 340 \\
\hline $\mathbf{1 9}^{\text {th }}$ & 138 & 109 & 40 & 19 & 11 & 0 & 26 & 343 \\
\hline $\mathbf{2 0}$ & 395 & 100 & 36 & 101 & 1 & 0 & 42 & 675 \\
\hline \hline total: & 616 & 992 & 165 & 179 & 62 & 56 & 603 & 2673 \\
\hline \hline
\end{tabular}

Table 4. Patterns: occurrences per century, basic numbers in percentage (based on IcePaHC)

\begin{tabular}{||l||r|r|r|r|r|r|r||c||}
\hline \hline & (I) & (II) & (III) & (IV) & DD-a & DD-b & DAN & total: \\
\hline \hline $\mathbf{1 2}^{\text {th }}$ & 0.7 & 89.0 & 4.1 & 1.4 & 1.4 & 0 & 3.4 & $100 \%$ \\
\hline $\mathbf{1 3}^{\text {th }}$ & 1.6 & 71.3 & 6.6 & 7.4 & 3.7 & 0 & 9.4 & $100 \%$ \\
\hline $\mathbf{1 4}^{\text {th }}$ & 0 & 75.3 & 8.4 & 2.9 & 1.7 & 0 & 11.7 & $100 \%$ \\
\hline $\mathbf{1 5}^{\text {th }}$ & 1.7 & 59.6 & 9.0 & 6.2 & 7.9 & 0 & 15.7 & $100 \%$ \\
\hline $\mathbf{1 6}^{\text {th }}$ & 1.1 & 27.7 & 4.0 & 2.8 & 3.4 & 5.6 & 55.4 & $100 \%$ \\
\hline $\mathbf{1 7}^{\text {th }}$ & 9.1 & 9.1 & 5.1 & 3.3 & 1.5 & 13.0 & 58.9 & $100 \%$ \\
\hline $\mathbf{1 8}^{\text {th }}$ & 12.6 & 33.5 & 2.1 & 1.5 & 2.9 & 0.9 & 46.5 & $100 \%$ \\
\hline $\mathbf{1 9}^{\text {th }}$ & 40.2 & 31.8 & 11.7 & 5.5 & 3.2 & 0 & 7.6 & $100 \%$ \\
\hline $\mathbf{2 0}^{\text {» }}$ & 58.5 & 14.8 & 5.3 & 15.0 & 0.1 & 0 & 6.2 & $100 \%$ \\
\hline \hline
\end{tabular}

As mentioned in Sect. 1.1.1, when discussing OI, I will also provide examples from MíM. The numbers based on queries in that corpus are as follows:

Table 5. Patterns in Old Icelandic: raw numbers and proportions (based on MÍM)

\begin{tabular}{||r|r|r|r|r|r|r||r||}
\hline (I) & (II) & (III) & (IV) & DD-a & DD-b & DAN & total: \\
\hline \hline 11 & 1776 & 212 & 176 & 105 & 2 & 37 & 2319 \\
\hline \hline $0.5 \%$ & $76.6 \%$ & $9.1 \%$ & $7.6 \%$ & $4.5 \%$ & $0.1 \%$ & $1.6 \%$ & $100 \%$ \\
\hline
\end{tabular}

As was also pointed out in Sect. 1.1.1, these numbers should be viewed as preliminary - as a point of departure, rather than definite results. 


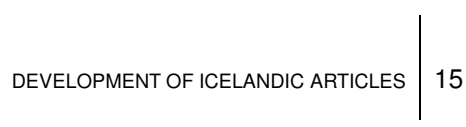

\subsection{Patterns with ART and/or DEF}

A first glance at tables 3/4 illustrate some interesting states of affairs:

- Pattern (I), albeit being the standard pattern in MI, is exceedingly rare up to the $16^{\text {th }}$ century; during that period, all other patterns (except for DD-b) are more frequent. Conversely, pattern (II), albeit being a marked pattern in MI, was the dominant pattern for many centuries, notably, during the OI period.

- Patterns (III) and (IV) are marked patterns in MI and have never been dominant; they have been marked patterns all along. Nonetheless, by consistently ranging in those low percentage numbers, they actually show a certain persistency or stability, differently from pattern (I).

- Something similar can be said about DD-a: although not very frequent, it shows a certain stability from the $12^{\text {th }}$ to the $19^{\text {th }}$ century. It is perhaps even more interesting to note that that pattern only disappeared relatively recently.

\subsubsection{Pattern (I)}

The development of pattern (I) is one of the most surprising facts about the results reported in tables 3-5. The proportional differences between earlier and later centuries are staggering, and so are the numerical and proportional discrepancies between patterns (I) and (II), especially before the $17^{\text {th }}$ century. For that period, there are only 10 attestations of pattern (I) in IcePaHC as opposed to 639 attestations of pattern (II). This tendency is strongly supported by the findings from MíM: I have only been able to identify 11 unambiguous cases of pattern (I) as opposed to more than 1,700 cases of pattern (II). This means that pattern (I) is virtually non-existent during the OI period, and really only caught on in the $17^{\text {th }}$ century, while pattern (II) is the dominant pattern during the OI period and still a prominent pattern up to the $19^{\text {th }}$ century. It is therefore worthwhile having a closer look at the oldest attestations of pattern (I); (25) lists all occurrences from the $12^{\text {th }}$ to the $16^{\text {th }}$ century in IcePaHC, and (26) gives the attestations in MÍM ( $~ 13^{\text {th }} / 14^{\text {th }}$ centuries) found so far:

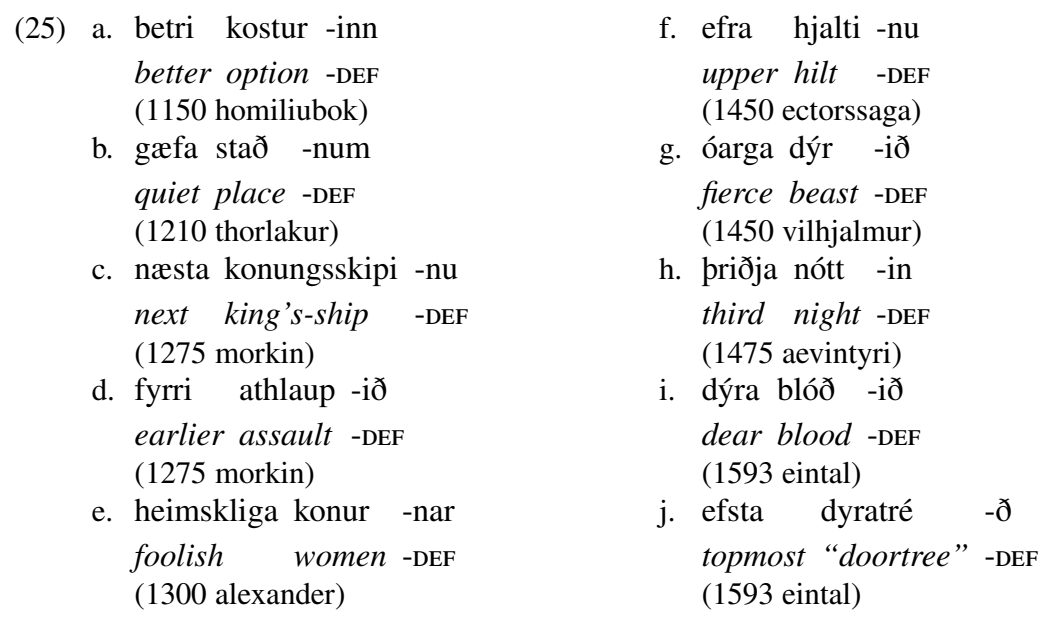


(26)
a. fyrri fjandskap -inn
earlier enmity -DEF
(Ljósvetninga saga)
b. fjórða vetur -inn
fourth winter -DEF
(Bjarnar saga Hítdælakappa)
c. fjórða dag -inn
fourth day -DEF
(Kjalnesinga saga)
d. mesta skipi -nu
biggest ship -DEF
(Flóamanna saga)
e. priðja myrgin -inn
third morning -DEF
(Laxdæla saga)
f. ytri stofu -na
outer room -DEF
(Sturlunga saga)

g. priðji maður -inn

third man -DEF

(Sturlunga saga)

h. priðja dag -inn

third day -DEF

(Sturlunga saga)

i. mesta styrk -inn

greatest strength -DEF

(Sturlunga saga)

j. priðja aftan -inn

third evening -DEF

(Sturlunga saga)

k. rauðflekkótta uxa -nn

red-speckled ox -DEF

(Vopnfirðinga saga)

It is possible that some more instances can be found, but this will hardly change the fact that pattern (I) is extremely rare. Conversely, it may be the case that not all examples listed above are genuine. For instance, (25-a) seems to be the oldest attested example, but possibly, it may have to be analyzed differently; compare:

(27) sá er betri kosturinn að taka eigi corpus Domini

SÁ is better option-DEF to take not corpus Domini

(ID 1150.HOMILIUBOK.REL-SER,.1891)

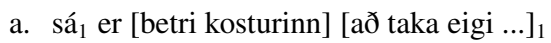

'that is the better choice, (namely) not to take ...'

b. [sá kosturinn [að taka eigi ...]] er betri

'the option not to take ... is better'

According to (27-a), the sequence betri kosturinn is indeed a pattern (I) noun phrase, in predicate function. ${ }^{19}$ But according to (27-b), the noun is part of the subject, while the adjective is part of the the predicate. This latter construal is feasible insofar as OI noun phrases may be discontinuous and extraction of the demonstrative sá is attested elsewhere, cf. (28-a), and predicative adjectives often precede the subject with the copula preceding the adjective, cf. (28-b) (both examples are from Njáls saga):

(28) a. ... spurðu hver sá væri sú hinn mikli maður

... asked who that was the big man

'... asked who that tall man was'

b. eru köld kvenna ráð

are cold women's advices

'Women's counsel is cold'

If this latter construal is correct, the oldest attestation of pattern (I) is actually from the $13^{\text {th }}$ century, viz. (25-b). Note also that example (25-e) is problematic because the ending $-a$ of the adjective is deviant; the expected (weak) ending would be $-u$. 
Alternatively, it could be the case that it is meant to indicate the strong inflection (expected form -ar). In that latter case, this example would actually have to be counted as an instance of pattern (IV). ${ }^{20}$ Finally, it is noteworthy that those few early attestations of pattern (I) mostly involve functional adjectives without genuine descriptive content: defective adjectives ${ }^{21}$ and ordinal numerals, or superlatives.

Thus possibly, some apparent attestations of pattern (I) may have to be discarded, and even that small number of pattern (I) noun phrases $(10+11)$ is too generous. And even for the authentic cases, there seems to be some kind of restriction: if pattern (I) at all, then preferably with some functional adjective.

The observation that pattern (I) is virtually absent in older stages is interesting in light of the fact that it has become the standard pattern in Modern Icelandic.

\subsubsection{Pattern (III)}

Tables 3-5 above show that pattern (III) has never been particularly prominent, but it has been attested from early on. Example (9) discussed in Sect. 1.2, repeated below, is one of the earliest attestations:

\section{(29) mirki -t mikla}

monument -DEF great

In that section, it was also mentioned that pattern (III) emerged from a constellation involving a postnominal adjectival article: N-DEF $\mathrm{A}<<\mathrm{N}$ ART A, which, according to one view, is also how the suffixed definite article itself came about, even though that view is controversial. However, regardless of whether DEF developed from ART or from a demonstrative in postposition, notice that, for many centuries, especially during the OI period, we find both those constellations just mentioned side by side. Recall that they will be referred here as patterns (III-a) and (III-b), respectively, see (6). It must be mentioned that the numbers for pattern (III) in tables 3-5 actually result from conflating patterns (III-a) and (III-b); ${ }^{22}$ the precise numbers and some examples are given below:

Table 6. Pattern (III): details (based on IcePaHC; cf. table 3)

\begin{tabular}{||l||r|r||r||}
\hline \hline & (III-a) & (III-b) & (III) = total \\
\hline \hline $\mathbf{1 2}^{\text {th }}$ & 3 & 3 & 6 \\
\hline $\mathbf{1 3}^{\text {th }}$ & 3 & 13 & 16 \\
\hline $\mathbf{1 4}^{\text {th }}$ & 7 & 13 & 20 \\
\hline $\mathbf{1 5}^{\text {th }}$ & 6 & 10 & 16 \\
\hline $\mathbf{1 6}^{\text {th }}$ & 4 & 3 & 7 \\
\hline $\mathbf{1 7}^{\text {th }}$ & 12 & 5 & 17 \\
\hline $\mathbf{1 8}^{\text {th }}$ & 6 & 1 & 7 \\
\hline $\mathbf{1 9}^{\text {th }}$ & 37 & 3 & 40 \\
\hline $\mathbf{2 0}^{\text {y }}$ & 36 & 0 & 36 \\
\hline \hline total: & 114 & 51 & 165 \\
\hline \hline
\end{tabular}


Table 7. Pattern (III) in Old Icelandic: details (based on MÍM; cf. table 5)

\begin{tabular}{||r|r||r||}
\hline (III-a) & (III-b) & $($ III $)=$ total \\
\hline \hline 62 & 150 & 212 \\
\hline \hline
\end{tabular}

(30) Pattern (III-a)
a. örn -inn gamli eagle -DEF old (Eyrbyggja saga)

b. saxi -nu góða sword -DEF good (1310 grettir)

(32) Pattern (III- $a)$

a. ormur -inn langi serpent -DEF long (Heimskringla)

b. hönd -ina hægri hand -DEF right (Laxdæla saga)
(31) Pattern (III-b)

a. myrkur hið mikla darkness ART great (Heimskringla)

b. kross inn helga cross ART holy (1150 homiliubok)

(33) Pattern (III-b)

a. ormur hinn langi serpent ART long (Heimskringla)

b. hönd hina hægri hand ART right (Fljótsdæla saga)

Consider (32) and (33): 'The long serpent' is the name of a famous Viking vessel; names have rigid reference and cannot mean different things in different contexts. Something similar applies to cases like 'the right hand'. This is a strong indication that patterns (III-a) and (III-b) are merely two superficial variants of the same expression, i.e. two (morpho-)phonological variants of the the same syntactic constellation, which justifies treating both as instances of pattern (III) in the first place. This, in turn, entails that the article element used in both (III-a) and (III-b) is actually the same: the adjectival article. In other words, even if we concede that DEF does not derive from ART, but from a demonstrative (see Sect. 1.2), it should still be acknowledged that the adjectival article can occur either as a free or a bound morpheme.

Minimal pairs like these, in turn, seem to support idea that ART and DEF in general are merely two surface varieties of the same article element, see Sect. 1.3. However, since various patterns of double definiteness are attested in OI, that conclusion becomes rather spurious. Apart from DD-a, discussed in the next subsection, we find interesting cases like these: ${ }^{23}$

(34) a. hest -inn hinn fífilbleika

$$
\begin{aligned}
& \text { horse -DEF ART dandelion-yellow } \\
& \text { (Víglundar saga) } \\
& \text { b. eld -inn pann hinn vígða } \\
& \text { fire -DEF DEM ART consecrated } \\
& \text { (Kjalnesinga saga) }
\end{aligned}
$$

We observe that both DEF and ART can simultaneously occur in the same noun phrase, either in direct adjacency or with an element intervening. Thus they cannot be the same element. The above observation that (III-a) and (III-b) are two varieties of the 
same syntactic constellation, and that the adjectival article can occur as a free or a bound element, does not necessarily entail that DEF and ART as such are two varieties of the same article element (see Sects 5.2/5.3).

\subsubsection{Double definiteness A}

According to table 3 (IcePaHC), DD-a is consistently attested as a marked pattern from the $12^{\text {th }}$ century onwards and disappears in the early $20^{\text {th }}$ century; ${ }^{24}$ recall that it is ungrammatical in MI. Prior to the $17^{\text {th }}$ century, it is somewhat more frequent than pattern (I). In this respect, table 5 (MÍM) suggests a stronger tendency for OI: we have 105 attestations of DD-a vs. 11 instances of pattern (I).

Lohndal $(2007,290)$ makes the following claim:

Double definiteness was not very common in ON [Old Norse], although some examples exist. Note that they are from the latter part of the ON period (approximately 1270-1330). A couple of examples are provided in [(35)]:

(35) a. ins versta hlutar -ins

ART worst part -DEF

(Faarlund 2004, 58) b. hinir beztu mennir -nir

ART best men -DEF

(Faarlund 2004, 58)

Here, some comments are in order. Firstly, Lohndal discusses the development of double definiteness in Norwegian, but examples like (35) instantiate the pattern that is referred to here as DD-a, but not the kind of double definiteness found in Modern Norwegian, which would be DD-b. Secondly, according to table 3, the oldest attestations are from the $12^{\text {th }}$ century - specifically, from the Hómiliubók, which is one of the oldest extant Icelandic texts - and not from the latter part of the period. Thirdly, while it is true that it is a rare pattern, it was shown that it is at least more frequent than pattern (I) up to the $16^{\text {th }}$ century. This leads to a fourth point: double definiteness did not just develop in Old Norse to only continue outside Iceland(ic); especially DD-a continued to exist as a marked pattern in Icelandic for a long time. Moreover, as will be discussed in the next section, DD-a has a development quite different from DD-b (see tables 3/4), which does have an interesting cameo appearance in Icelandic. The two should not be simply conflated into one double definiteness phenomenon.

\section{2 sá as adjectival article}

In Icelandic, the adjectival article hinn (ART) has survived to this day, even though its relevance has diminished due to the prominence of pattern (I). In the NIScan languages, on the other hand, it has almost entirely disappeared while the distal demonstrative sá has taken its place (DET; see introduction). It is therefore interesting to note that the same development, a competition between hinn and sá, was in progress in Icelandic, but with a different outcome: sá did not replace hinn.

In this subsection, I will examine two more patterns: DD-b and DAN both of which involve the distal demonstrative sá. 
$20 \mid$ ALEXANDER PFAFF

\subsubsection{Double definiteness B}

DD-b is rather uncommon in OI. In MÍM, the following two examples are attested:
(36) a. öll pau góđu tillög -in all sÁ good counsels -DEF (Sturlunga saga)
b. sá rauði uxi -nn
sá red ox -DEF
(Vopnfirðinga saga)

The findings in IcePaHC essentially draw the same picture; but they also illustrate an interesting development after the OI period. According to tables 3/4, DD-b is not attested in the earlier stages, "suddenly" appears in the $16^{\text {th }}$ and $17^{\text {th }}$ centuries, and disappears again during the $18^{\text {th }}$ century. Recall that Lohndal argues that double definiteness is a late development, see Sect. 3.1.3. With the numbers above, we can relativize that claim: it is definitely true for DD-b (in Icelandic), while it does not apply to DD-a. But while DD-a remains a marked pattern throughout, DD-b, during its brief appearance, becomes the second strongest pattern in the $17^{\text {th }}$ century; it is more frequent than patterns (I)-(IV) and DD-a, respectively.

Already in the $16^{\text {th }}$ century, when DD-b first appeared according to IcePaHC, it occurs in essentially the same contexts as DD-a. The following minimal pair from Guðbrandsbiblía ${ }^{25}$ (printed 1584; Genesis 2) is rather revealing:
a. Hið priðja vatsfall -ið heitir Hídekel (DD-a) ART third stream -DEF is-called Hiddekel 'the third stream'
b. Рað fjórða vatsfall -ið er Eufrates
SÁ fourth stream -DEF is Euphrates
(DD-b) 'the fourth stream'

Here DD-a and DD-b occur in identical (syntactic, semantic, information-structural) contexts. The two are in free variation, or to put it differently: they are in direct competition. So for a brief period, pattern DD-b was on its way to becoming an etablished pattern. This raises some questions: Firstly, given that double definiteness started spreading in the first place, why was it not DD-a, which had been around for a longer time, that gained ground? Secondly, why did DD-b disappear as suddenly as it appeared? A partial answer to these questions will be given in the following; it will emerge that the competition starting around the $16^{\text {th }}$ century is not so much between DD-a and DD-b, but rather between the elements hinn and sá.

\subsubsection{The "Danish" pattern}

As can be seen in tables $3 / 4$, pattern DAN has been attested from the $12^{\text {th }}$ century onwards (although very rare in OI according to MíM, cf. table 5); its frequency increases in small steps until the $15^{\text {th }}$ century. During the $16^{\text {th }}$ and $17^{\text {th }}$ centuries, it becomes the dominant pattern (it is more frequent than all other patterns together). During the $18^{\text {th }}$ century, it still remains a strong pattern, but in the $19^{\text {th }}$ century, its frequency decreases drastically and patterns (I) and (II) gain the upper hand.

Similarly to (37), we find pattern (II) vs. DAN minimal pairs from the $16^{\text {th }}$ 
century onwards; example (38-a) below is taken from Oddur Gottskálksson's introduction to his translation of the New Testament (printed 1540): ${ }^{26}$
(38) a. hið nýja testament
ART new testament 'The New Testament'

b. pað nýja testament

sá new testament 'The New Testament' (1593 eintal)

It is worthwhile considering some historical background: i.) The Reformation on Iceland (mid-16 $6^{\text {th }}$ century) was instigated by the Danish king, and in the wake of the Reformation, the Danish influence on Icelandic grew stronger. In all likelyhood, the strong increase of the the "Danish" pattern is related to this increased Danish influence, one way or another. ${ }^{27}$ ii.) The $19^{\text {th }}$ century saw the advent of the socalled málhreinsunarstefna ("language purification movement") in Iceland where widely successful attempts were made to purge Icelandic of foreign - especially Danish - influences. So it may not be totally coincidental that the "Danish" pattern largely disappeared again during the $19^{\text {th }}$ century.

\subsubsection{Adjectival article?}

The brief appearance of DD-b coincides with the strong increase in frequency of DAN; both patterns use sá. Given that grammaticalization of (distal) demonstratives into articles is a well-known development, one likely interpretation of the data in table 4 is that sá was in the process of grammaticalizing into a definite article from the $16^{\text {th }}$ century onwards. But this statement must be relativized: the increased frequency of sá is only observed in the context of adjectival modification. Table 2 illustrates that, globally (i.e. irrespective of modification), the frequency of $s a ́$ remains relatively constant throughout the centuries - unlike the frequency of the suffixed definite article (DEF); the relevant columns of that table are repeated below:

Table 8. DEF and sá, basic numbers in percentage (from table 2; IcePaHC)

\begin{tabular}{||l||r|r|r|l||}
\hline \hline & $\ldots$ & DEF & sá & $\ldots$ \\
\hline \hline $\mathbf{1 2}^{\text {th }}$ & & 6.7 & 5.1 & \\
\hline $\mathbf{1 3}^{\text {th }}$ & & 15.6 & 5.8 & \\
\hline $\mathbf{1 4}^{\text {th }}$ & & 13.1 & 4.9 & \\
\hline $\mathbf{1 5}^{\text {th }}$ & & 18.3 & 3.9 & \\
\hline $\mathbf{1 6}^{\text {th }}$ & & 20.0 & 5.2 & \\
\hline $\mathbf{1 7}^{\text {th }}$ & & 19.8 & 5.6 & \\
\hline $\mathbf{1 8}^{\text {th }}$ & & 17.4 & 4.5 & \\
\hline $\mathbf{1 9}^{\text {th }}$ & & 25.9 & 2.8 & \\
\hline $\mathbf{2 0}^{\text {» }}$ & & 31.4 & 2.3 & \\
\hline \hline
\end{tabular}

At least initially, it seems as though sá was specifically developing into an adjectival article and about to supercede hinn in that function (which is, in fact, what had happened in the NIScan languages some centuries earlier (see e.g. Stroh-Wollin 2009, 2015a). Table 9 shows the frequencies of adjectival articles, where ART represents patterns (II)/DD-a, and sá represents patterns DD-b/DAN: 
22 ALEXANDER PFAFF

Table 9. Adjectival articles: numbers in percentage (based on the numbers in table 3; IcePaHC)

\begin{tabular}{||l||r|r||l||}
\hline \hline & ART & SÁ & total: \\
\hline \hline $\mathbf{1 2}^{\text {th }}$ & $\mathbf{9 6 . 3}$ & 3.7 & $100 \%$ \\
\hline $\mathbf{1 3}^{\text {th }}$ & $\mathbf{8 8 . 8}$ & 11.2 & $100 \%$ \\
\hline $\mathbf{1 4}^{\text {th }}$ & $\mathbf{8 6 . 7}$ & 13.3 & $100 \%$ \\
\hline $\mathbf{1 5}^{\text {th }}$ & $\mathbf{8 0 . 5}$ & 19.5 & $100 \%$ \\
\hline $\mathbf{1 6}^{\text {th }}$ & 32.9 & $\mathbf{6 7 . 1}$ & $100 \%$ \\
\hline $\mathbf{1 7}^{\text {th }}$ & 12.2 & $\mathbf{8 7 . 8}$ & $100 \%$ \\
\hline $\mathbf{1 8}^{\text {th }}$ & 43.3 & $\mathbf{5 6 . 7}$ & $100 \%$ \\
\hline $\mathbf{1 9}^{\text {th }}$ & $\mathbf{8 2 . 2}$ & 17.8 & $100 \%$ \\
\hline $\mathbf{2 0}^{\text {» }}$ & $\mathbf{7 0 . 6}$ & 29.4 & $100 \%$ \\
\hline \hline
\end{tabular}

Table 9 shows that, in the $16^{\text {th }}$ century, sá becomes the dominant adjectival article, and, given minimal pairs like (37) and (38), this means that it is in direct competition with hinn. ${ }^{28}$ However, hinn continues to exist (in that function), and in the $19^{\text {th }}$ century, it re-gains the upper hand, in contrast to what happened in the NIScan languages.

It should be emphasized that sá has retained its semantics/function as a distal demonstrative throughout, and in some instances of DD-b/DAN, it may actually have a demonstrative interpretation. ${ }^{29}$ But most examples of the period in question do have an unambiguous article (= simple uniqueness) interpretation (see also (38)):

(39)
a. bað eilífa líf -ið
sÁ eternal life -DEF
'(the) eternal life'
(1593 eintal)
b. bess Nýja testamentis -ins sá new testament -DEF 'The New Testament' (1593 eintal)

c. bví eilífa lífi sá eternal life '(the) eternal life' (1630 gerhard)

d. pað nýja testament sá new testament 'The New Testament' (1593 eintal)

This observation and the striking (proportional) increase of sá specifically in the context of adjectivally modified noun phrases anyway support the assessment that $s a ́$ entered a process of developing into an adjectival article as in the NIScan languages - at least for a certain period. ${ }^{30}$

Yet another aspect must not be ignored: even though hinn became the dominant adjectival article once more during the $19^{\text {th }}$ century, it was pattern (I) that has eventually become the dominant pattern, not pattern (II). In this sense, the develoments discussed above do not merely illustrate one process, but an intricate interaction of several processes/competitions, minimally: sá vs. hinn vs. pattern (I).

\subsection{Summary}

The two most striking observations made in Sect. 3.1 are (i) the virtual absence of pattern (I) prior to the $17^{\text {th }}$ century, and (ii) the fact that the double definiteness pattern DD-a existed in Icelandic until the early $20^{\text {th }}$ century. The fact that ART and DEF could coocur for a long time suggests that, during that time, those two elements oc- 
cupied different positions in the noun phrase structure and had a different categorial status (compare this with what was said about MI in Sect. 2.1).

The developments sketched in Sect. 3.2 in all likelihood indicate an incipient grammaticalization process where the demonstrative sá was en route to supercede hinn as an adjectival article. Pattern DAN increased markedly in frequency in the $16^{\text {th }}$ century. This acceleration is likely to have been due to Danish influence, especially in the wake of the Reformation (see fn. 27). Double definiteness pattern DD-a had been around since the $12^{\text {th }}$ century and continued to exist for a long time. Notwithstanding what caused its emergence in the first place, it is conceivable that the existence of that pattern in conjunction with the increase in frequency of sá boosted the development of pattern DD-b. If the macro process really was about the element $s a$, it explains why both DD-b and DAN gain in frequency during the $16^{\text {th }} / 17^{\text {th }}$ centuries. But it would seem as though, at some point, the Danish influence was so strong that DD-b disappeared - while DD-a continued to exist.

Approximately between the $16^{\text {th }}$ and $19^{\text {th }}$ century, there was a competition between two adjectival articles; hinn continued to exist, and was not replaced by sá. In the course of the $19^{\text {th }}$ century, the Danish pattern largely disappeared, and hinn won the competion over sá as an adjectival article. In parallel, since the $17^{\text {th }}$ century, pattern (I) had steadily gained in frequency, and eventually becomes the dominant pattern.

\section{Adjectival Article}

In the last section, the notion of adjectival article was used losely to refer to some determiner element that cooccurs with an adjective. But as mentioned in Sect. 1.3, even though some prominent analyses assume that $(h)$ inn is a genuine determiner in OI occupying an immediate $\mathrm{X}^{0}$ position in the nominal projection, there are also many views according to which (h)inn belongs specifically with the adjective (Nygaard 1906; Heinrichs 1954; Lundeby 1965; Perridon 1996; Himmelmann 1997; Skrzypek 2009, 2010; Perridon and Sleeman 2011; Stroh-Wollin 2009, 2015a, 2016; Rießler 2016; Börjars and Payne 2016; Börjars et al. 2016). In formal terms, this narrow conception of the notion adjectival article entails that ART is is not an immediate constituent of the nominal projection (xNP), but a component of AP; this is stated explicitly and formalized in Börjars and Payne (2016); Börjars et al. (2016). I will adopt this idea and elaborate on it in the following.

\subsection{Adjectival article and weak inflection}

There is a particularly intimate relationship between (h)inn and weakly inflected adjectives: from the oldest attestation onwards, (h)inn only occurs with an immediately following weak adjective (except for demonstrative uses, see (3), Sect. 1.2). This dependency is not entirely mutual, but there is a strong tendency: the further we go back in time, the more a weak adjective is dependent on cooccurring (h)inn, the closer we come to the present, the more independent weak adjectives become. Perridon (1996) identifies six occurrences of bare weak adjectives 
(i.e. weakly inflected adjectives not preceded by (h)inn) in the Swedish runic corpus: aningi/aninga "only-one", bazti "best", fyrsta "first", priðia "third", and ungu (uku) "young". However, Stroh-Wollin (2012) argues against interpreting that last one as weak adjective, and suggests instead that it has to be read as name. If so, the only remaining bare weak adjectives are functional adjectives and superlatives. ${ }^{31}$ Otherwise, weakly inflected adjectives are preceded by the adjectial article ( $h$ )inn in the oldest attestations (or sá/parn in Old East Norse, see Sect. 6.1).

In OI, bare weak adjectives can be found, but they are still exceptional. Again, normally, a weak adjective is preceded by (h)inn. Occasionally, weak adjectives occur with other formally definite elements, such as demonstratives (see Sect. 4.3 below on possessives); as for $s a ́$ + A.wK, see the discussion on pattern DAN (tables $3 / 5$ and Sect. 3.2.2); as for pessi ("this") + A.wK, I have found 13 instances in MÍM (so far). However, here it should be pointed out that demonstratives often do not occur with a bare weak adjective; quite often there is an additional ART preceding the weak adjective (at least 100 instances in MÍM), cf. (40), and sometimes, demonstratives also occur with strong adjectives (at least 20 occurrences in MíM), cf. (41):

(40) a. pann hinn digra mann SÁ ART stout.WK man (Heimskringla)

(41) a. Pessi vond-ur svikari DEM evil-STR traitor (Íslendinga pættir) b. pessi hin sömu orð

DEM ART same.wK words

(Fljótsdæla saga)

b. peim norræn-um manni SÁ Nordic-STR man (Fóstbræðra saga)

This is a clear indication that demonstratives are not on par with ART in OI, neither categorially nor functionally. On the other hand, in MI, we systematically find DEM + A.wK instead of patterns like (40)/(41).

The specific relationship between (h)inn and weak adjectives is summed up by Stroh-Wollin $(2009,7)$ : “(h)inn [...] seems to be just a formal element preceding adjectives with so called weak inflection"; Börjars and Payne $(2016,2)$ propose that "(h)inn [...] is a functional element whose role it is to allow a weak adjective to function as an ADJ". Taken together, all this suggests that bare weak adjectives, in some sense, are not "complete" adjectival constituents , and ART can be understood as an adjectival complementizer, as it were. I will adopt the view that one function of ART is to complement (or license) a weak adjective (see (24) in Sect 2.2) rendering it a "complete" AP (see also (64)). Conversely, on this same view, strong adjectives should be considered complete. ${ }^{32}$ In the following subsections, I will present some observations that illustrate how strong adjectives and the sequence ART + A.wK appear to behave as two varieties of the same category: AP.

\subsection{Absolute superlatives and predicative APs}

Pattern (II) noun phrases involving a superlative adjective often occur in predicative position yielding a so-called absolute/indefinite superlative interpretation: 
(42) a. Púríður var hin vitrasta kona

púríður was ART wise.SUPL.WK woman

"Púríður was a very wise woman"

(Flótsdæla saga)

b. Hann [...] var hið mesta illmenni

he was ART big.SUPL.WK villain

"he was 'the greatest' villain (i.e. a very bad person)"

(Brennu Njáls saga)

Under certain cirumstances, the noun may be missing: ${ }^{33}$

(43) a. Gunnar var hinn reiðasti

Gunnar was ART angry.sUPL.WK

"Gunnar was very angry"

(Brennu Njáls saga)

b. konungur var hinn glaðasti

king was ART glad.sUPL.WK

"the king was very glad"

(Bárðar saga Snæfellsáss)

In examples like these, the sequence ART A.wK is interpreted as a predicate (of type $<\mathrm{e}, \mathrm{t}>$ ) - just as other APs in predicative position. Furthermore, this sequence can be coordinated with "proper" APs headed by a strongly inflected adjective:

(44) a. Var pað lið [hið fríðasta] og [vopnað allvel]

was that army ART fine.SUPL.WK and armed.STR all-well

'That army was very fine (= consisting of fine men) and extremely well armed' (Egils saga Skallagrímssonar)

b. hann var [...] [hinn vasklegasti] og [fullur af ofurkappi]

he was ART brave.SUPL.WK and full.STR of over-eagerness

'he was very brave and full of over-eagerness'

(Pórðar saga hreðu)

In other words, interpretation suggests that the bare sequence ART A.wK behaves like a predicate, and coordination suggests that it behaves like an AP headed by a strong adjective. But while an interpretation as a referential elliptic noun phrase is not an option for examples like (43) ( "he was the most angry one"), it does not yet follow that ART A.wK does constitute an AP. In fact, one might argue that, strictly speaking, the above merely shows that the sequence can have a predicative semantic type on a par with strong APs. It does not rule out, as such, that that sequence is an elliptic predicative NP (also of type $<\mathrm{e}, \mathrm{t}>$ ). After all, predicative NP \& AP coordinations are well-known ('she is [a linguist] and [proud of it]'). In the next subsection, I will loook at another distributional criterion.

\subsection{Complementary distribution}

In MI, adjectives following a possessive must be weakly inflected (as in NIScan more generally), both in pre- and postnominal position, even in the absence of a definite article. Moreover, possessives cannot be followed by ART: 
(45) a. pín/hans hetjulega / *hetjuleg barátta your/his heroic.wK / heroic.sTR battle

b. tengdaforeldrar mínir/hennar væntanlegu / *væntanlegir parents-in-law my/her prospective.wK / prospective.sTR

c. pín/hans (*hinn) hetjulega barátta your/his ART heroic.wK battle

In contrast, in OI/Old Norse, adjectives following a possessive are usually strongly inflected, ${ }^{34}$ both prenominally and postnominally, (46). Alternatively, a possessive precedes the sequence ART + A.WK, (47): ${ }^{35}$

(46) a. sinni fullkominni vináttu Poss perfect.sTR friendship (Sturlunga saga)

b. öxi sína forna axe poss old.sTR (Sturlunga saga)
(47) a. bín hin mesta gæa your ART greatest.wK luck (Njáls saga)

b. æsing sinn hinn mikla fury POss ART great.wK (Vatnsdæla saga)

On the other hand, bare weak adjectives are highly exceptional in this context (the numbers are based on MíM):
(48) POSSESSIVE A.sTR: $\quad 80(64.5 \%)$
possessive Art A.wK: $35(28.2 \%)$
POSSESSIVE A.wK: $\quad 5(4.0 \%)$
POSSESSIVE A.UNDEC: $\quad 4 \quad(3.2 \%)$
(of which 3 superlatives)

The generalization is that, in certain contexts, strongly inflected adjectives and the sequence ART A.WK are in complementary distribution, but bare weak adjectives are excluded from the same position. Put slightly differently, there are two varieties of AP: $[A P$ A.sTR ] and [AP ART A.wK ], that occur in the context Possessive + AP.

In a weaker sense, the argument from complementary distribution could also be made for demonstratives, cf. (40)/(41) (and possibly other contexts). Complementary distribution can be seen as a direct reflection of the idea suggested in Sect. 4.1, that bare weak adjectives - differently from strong adjectives - are not complete APs in OI and require ART as an adjectival complementizer.

By the same token, of course, considering (45), this reasoning entails that bare weak adjectives are actually complete APs in MI, since they now occur in contexts where they were not found previously. It also follows that ART is not a component of the AP any longer in MI (see Sect. 4.5 for another difference between OI and MI).

\subsection{Occurrence per adjective}

In some cases of adjectival coordination both adjectives are preceded by ART: ${ }^{36}$

(49) a. hina efnilegustu menn og hina hraustustu

ART promising.SUPL men and ART valiant.SUPL 'the most promising and (most) valiant men'

(Finnboga saga ramma) 
b. Pú hið arga og hið illa kvikindi

you ART vile and ART evil creature 'you vile and evil creature'

(Flóamanna saga)

Examples like these are a strong indication that ART is more closely associated with the adjective than the noun phrase as a whole. This view is also supported by the fact that these noun phrases denote exactly one referent; both adjectives modifiy the same noun and do not belong to different noun phrases. The same point can be made more clearly. As was mentioned above, in OI, ART and the distal demonstrative sá frequently cooccur in the same noun phrase with ART preceding the adjective:

(50) a. pau hin spaklegu fræði

SÁ ART sagacious lore

(1150 firstgrammar)

(NB: *ART SÁ A ...) b. pann vetur hinn sama

SÁ winter ART same

(1210 jartein)

(NB: *ART N sá A)

Examples like these show that sá and ART belong to distinct categories and have different distributions. This is particularly noticeable in adjectival coordination structures:

(51)

a. skaða pann hinn mikla og hinn illa

damage sá ART extensive and ART bad

'that extensive and bad damage'

(Brennu Njáls saga)

b. sá hinn mikli og hinn feiknlegi er fjórir menn ganga fyrri

SÁ ART big and ART frightening whom four men walk before

'that tall and frightening (guy) before whom four men walk'

(Brennu Njáls saga)

c. beim hinum smám og hinum fám skipum

SÁ ART small and ART few ships

'those few small ships'

(Sturlunga saga)

Here we find one sá per noun phrase, but one ART per adjective, which iterates the point that ART belongs more closely with the adjective rather than with the noun phrase. This in conjunction with the above observations strongly corroborates the idea that ART forms a constituent with a weak adjective (= AP) to the exclusion of the noun and does not associate with the xNP directly. ${ }^{37}$

\subsection{Numerals}

When it comes to numerals, the present analysis has two options: either (a) OI treated numerals as adjectives, in which case we should expect the adjectival article in case of numerals as well, or (b) OI did not treat numerals as adjectives, in which case numerals should never intervene between ART and the adjective. ${ }^{38}$ On the other hand, if ART were in fact a determiner, we would expect numerals to intervene between the two (cf. Cinque 2005). Therefore, if (b) were to be confirmed, 
there would be a strong argument for the proposal that the ART is in fact associated with AP rather than xNP.

The only genuine example of ART + numeral that I have found is the following:

(52) er hinir prír eyxn gingu upp

when ART three oxen went ashore

(1260.JOMSVIKINGAR.NAR-SAG,.152)

In IcePaHC and MÍM, there are some further instances of hinn + numeral, but in all those cases, hinn has to be interpreted as as a demonstrative "the-other" (hinir tveir "the other two"), not as an adjectival article. Thus, normally, numerals are not treated as adjectives in that they occur without ART. More to the point, there are no indications that numerals (can) intervene between ART and adjectives in OI.

In MI, in contrast, numerals do intervene between ART and adjectives (see also Pfaff 2015, 31,95): ${ }^{39}$

(53) hinar fjórar frægu kenningar (cf. Sigurðsson 1993)

ART four famous.wK theories

In other words, these observations further corroborate the present claim that ART is narrowly associated with the adjective ( $=$ is a part of AP) to the exclusion of the noun in OI. Likewise, based on that criterion, by comparison, it follows that ART has a different status in OI and MI in that it is no longer directly associated with the adjective in MI, but with the larger noun phrase (=xNP).

\subsection{Excursus: Nominal APs? A tentative sketch of the pre-history}

The picture that emerges for OI is that ART is not a determiner in the nominal projection, but a component of AP, and, at least in the cases considered so far, the bare sequence ART A.wK can be argued to be an AP - rather than a noun phrase. However, recall from Sect. 1.2 that the oldest attestations mostly involve proper names where the (postnominal) sequence (h)inn $+\mathrm{A}$ acts as an epithet: ${ }^{40}$

\section{(54) a. bali hi- raupi (Vs 15) \\ Balli ART red.wK ("Balli the Red") \\ b. sontulf hin suarti (Vs 15) \\ Sandulfr ART black.wK ("Sandulfr the Black")}

Epithets of this kind, occurring with a proper name can be argued to be nominal in character in that they have a name-like function/distribution themselves (like a surname). So for instance Rießler (2016, 52/53), who discusses this type of epithets ("Frederick the Great") involving an adjectival (in his terminology: attributive) article under the heading "attributive nominalization", treats them as NPs.

Tentatively, I propose a double construal of the sequence ART + A.wK as either $\mathrm{AP}$ or $\mathrm{xNP}^{41}$ and briefly sketch a preliminary diachronic analysis. Since this proposal is (by its very nature) speculative, I will not go into much detail. The logical steps are summarized in the following table and commented upon below: 


\begin{tabular}{|c|c|c|c|}
\hline Indoeuropean & Germanic & Proto Norse & Viking Period \\
\hline " $\left[{ }_{x N P} \mathrm{~A}\right]$ & $\begin{array}{l}{ }_{x N P} \text { A.WK ] } \\
{\left[{ }_{A P} \text { A.stR }\right]}\end{array}$ & $\begin{array}{c}\left.{ }_{x N P} \text { DEM A.WK }\right] \\
{\left[{ }_{A P} \text { A.sTR ] }\right.}\end{array}$ & $\begin{array}{c}{\left[{ }_{x N P} \text { ART A.WK }\right]} \\
{\left[{ }_{A P} \text { ART A.wK ] }\right.} \\
{\left[{ }_{A P} \text { A.sTR }\right]}\end{array}$ \\
\hline
\end{tabular}

1. It has been proposed that IE did not have a seperate morpho-syntactic category "adjective", but only one category "nominal" comprising what we might otherwise consider adjectives and nouns. Instead of attribution, IE employed close apposition where two nominals constitute one macro noun phrase. A distinct category "adjective" emerges as a result of the diachronic development from IE towards her daughter languages (e.g. Werner 1984; Viti 2015; Adrados et al. 2016; see Rehn 2018 for discussion and further references).

2. The IE daughter language Germanic does have a separate class "adjectives". But simultaneously, another innovation takes place, viz. the establishment of a second adjectival paradigm, traditionally referred to as weak inflection. The precise origin and original function of the weak inflection are still a matter of debate. One approach suggests that it primarily had a nominalizing function (Osthoff 1876; Kovari 1984). Although not uncontested (see Curme 1910; Ringe 2006; Ratkus 2011; Rehn 2018 for discussion), I will adopt this idea and interpret it in such a way as to mean that a weakly inflected adjective at the early Germanic stage essentially heads a nominal projection.

3. If weak adjectives are indeed at the center of a nominal projection, it is not surprising that such a projection may also host a (presumably semantically weakened) demonstrative as an immediate component. Considering that the oldest attestations of the sequence (h)inn + A.wK are, in fact, appostions (epithets), we may, in a sense, view weak adjectives as a continuation of the IE mode of modification: apposition involving nominals. In other words, in Proto Norse, demonstrative (h)inn + A.wK constitute an appositive noun phrase.

4. Now assume that, at some point, when occurring with common nouns rather than proper names, the appositive nominal projection was categorially re-analysed as AP. This reanalysis at the phrasal level may have become an option because the sequence ART + A.WK and strong adjectives increasingly occurred in identical contexts. It may also have been enforced by the facts that both used the same (= adjectival) stems. At the same time, (h)inn had largely lost its demonstrative force and its function as a determiner element in that context - but adopted a new function, see Sect. 4.1.

If the development of weak adjectives and (h)inn did roughly proceed along these lines, it would explain how an element that started out as an element of a nominal projection (demonstrative) ended up as an adjectival article "trapped" in an adjectival projection. It also suggests that the nominal construal of $(h)$ inn + A.wK is the older one, and the construal as AP is an innovation; still, both construals coexisted at least throughout the OI period. 


\section{Nominal Article}

In Sect. 1.2, two competing approaches to account for the genesis of the suffixed article (DEF) were discussed: reanalysis of a cliticized adjectival article and reanalysis of a demonstrative in postposition. In this section, I will propose that the relevant reanalysis involves the emergence of a genuinely new element: a nominal article.

\subsection{Prosodic unit reanalyzed as morphosyntactic unit}

Taking the schematic (12) as a point of departure, (h)inn is a demonstrative in stage A, but in stage B, it represents the adjectival article ART (see previous section):

(56) A: $\mathrm{N}[$ DemP hinn ]

B: $\quad \mathrm{N}\left[{ }_{A P}(h)\right.$ inn A.wk ] $\quad$ = pattern (III-b)

At some point, constellation B gives rise to cliticization to the effect that the noun and the reduced version of ART form a prosodic unit, cf. examples $(9) /(10)$ :

(57) C: $\mathrm{N}\left[{ }_{A P}-\right.$ inn A.wK ]

$=$ pattern $($ III-a)

Since this step is understood here as a purely phonological process, the article element, albeit now manifesting itself as DEF, is still construed as an adjectival article in AP, not an element of the nominal projection. If we follow the idea that the suffixed article developed from a demonstrative, see Sect. 1.2, we have to assume a similar intermediate stage where a prosodically (and presumably semantically) weakened demonstrative forms a merely phonological unit with the preceding noun:

(58) C': $\mathrm{N}[\operatorname{DemP}(-)$ inn $]$

Glossing over the question whether $\mathrm{C}$ or $\mathrm{C}^{\prime}$ is the relevant input constellation, the decisive step occurs now: at some point, a prosodic unit gives rise to a reanalysis as a morpho-syntactic unit:

$$
\text { D: }\left[{ }_{n P} \mathrm{~N}-i n n\right]
$$

Only this step indicates the emergence of a new element: a "nominal" article. This nominal article forms with the noun - and nothing else - a syntactic constituent, and thus has scope only over the noun. Following Lohndal (2007) (see Sect. 1.3), I will refer to that constituent as $\mathrm{nP}$.

Moreover, I will follow Lohndal in assuming that this projection did not exist in the language prior to reanalysis. Recall, however, that, according to Lohndal, this process took place in the latter part of the Old Norse period (late $13^{\text {th }} /$ early $14^{\text {th }}$ century). I will not attempt to give a precise date, but I will pre-date the terminus ante quem. Given the oldest attestation of a bare definite noun, cf. (11), I suggest that reanalysis and the emergence of the nominal article/nP must have taken place, at the latest, during the $11^{\text {th }}$ century, at any rate before the Old Icelandic period. This is still compatible with Stroh-Wollin (2016) who suggests that it took place around the year 1000 (but not necessarily with Skrzypek $(2009,2010)$ who argues that the formation of the suffixed article must have happened before 800). 


\subsection{Modified and "bare" definite noun phrases}

Recall the minimal pairs (32) and (33) repeated below:

(60) Pattern (III-a)

a. ormur -inn langi serpent -DEF long

b. hönd -ina hægri hand -DEF right
(61) Pattern (III-b)

a. ormur hinn langi serpent ART long

b. hönd hina hægri hand ART right

Based on alternations like these I argued that the article element involved in both is the same, viz. the adjectival article. However, given reanalysis and the emergence of a nominal article as suggested in the previous subsection, we are now faced with an ambiguity: the item -inn, glossed as DEF, can be (i) a phonological variant of the adjectival article in the context of pattern (III-a), or (ii) the nominal article; that is it can be either an element of AP or of nP. I suggest that reanalysis did not simply replace the construal of the suffixed article of stage $C$ as an adjectival article and that the construal as a prosodic unit of stage $\mathrm{C}$ must have been available for a certain period even after reanalysis. What kept the construal of DEF as an adjectival article in pattern (III-a) alive presumably had to do with the existence of pattern (IIIb), and (III-a)/(III-b) alternations like (60)/(61). Notice that this is independent of whether the nominal article derived from ART or from the demonstrative, i.e. independent of whether it was $\mathrm{C}$ or $\mathrm{C}^{\prime}$ that gave rise to reanalysis $\mathrm{D}$. In the latter case, it would mean that it is due to an etymological coincidence (ART itself also derives from the same demonstrative) that the cliticized form of ART and the nominal article appear to be identical regarding stem (-in-) and inflection. In short, according to my analysis, two distinct items, the adjectival and the nominal article, can have the same morpho-phonological shape and both be glossed as DEF, while $(h)$ inn, glossed as ART, is unambiguously the adjectival article. Conversely, according to the analyses by Roehrs and Sapp 2004; Faarlund 2004, 2007, 2009; Lohndal 2007; Laake 2007 (see also Sect. 1.3), there is one lexical item (the definite article) that is ambiguous between two morpho-phonological shapes (free and suffixed). This seemingly rather subtle difference between analyses has concrete ramifications when it comes to the relationship between article and adjective.

It has been pointed out that the freestanding adjectival article (ART) only occurs with a weak adjective. On the present analysis, this is captured by the assumption that it is in fact an element of AP. On the other hand, Faarlund $(2009,629)$ proposes that there is a selectional restriction in the freestanding article ART requiring it to merge with an $\alpha \mathrm{P}$ (a functional projection hosting an AP in its specifier), which is another way of capturing the fact that it only occurs with adjectives. But if ART has this kind of selectional restriction and if ART and DEF are identical (which is the case on Faarlund's account), then the suffixed article DEF would be expected to also select an adjective, and thus to only occur as pattern (III-a). Alternations like (60)/(61) would indeed be captured by this approach, if there were nothing more. However, the fact that "bare" definite nouns (N-DEF) are already widely attested in the oldest texts shows that the suffixed article is not as such dependent on an adjective; in other 
words, every attested bare definite noun is in violation of this selectional restriction.

On the other hand, a distinction between adjectival and nominal article along the lines sketched in the previous subsection allows us to preserve the conclusions drawn in Sect. 3.1.2 about the identity of (60) and (61) (both involve an adjectival article), while simultaneously accounting for the fact that not every suffixed article requires the presence of an adjective: the adjectival article manifesting itself as ART or DEF categorically requires the presence of an adjective, the nominal article only occurring as DEF merely requires the presence of a noun.

On a related note: in Sect. 1.2, I pointed out that the suffixed article usually does not occur on proper names, but also showed that there appear to be exceptions, cf. (10). With a categorial distinction between adjectival and nominal article, rather than a mere morpho-phonological one between ART and DEF, I can reduce the "exceptionality": only the adjectival article can occur cliticized to a name, not the nominal article.

\subsection{Double Definiteness}

Consider the following examples repeated from (34):

(62) a. hest -inn hinn fífilbleika

horse -DEF ART dandelion-yellow

b. eld -inn pann hinn vígða

fire -DEF DEM ART consecrated

Compare (62) with (60)/(61): while ART is obviously the same element in both (62) and (61), this is not obviously the case for DEF in (62) and (60). On the present approach, the adjective occurs with an adjectival article in all three cases, which can be ART: (62) and (61), or DEF: (60). In addition, independently of the adjective, the noun may carry its own nominal article, which only occurs as DEF: (62). This reiterates the point from the previous subsection that DEF allows for two construals, but it also highlights another aspect: double definiteness.

One obvious consequence of reanalysis is that, now, there are two distinct elements occupying two distinct positions: nominal article $\neq$ adjectival article, and their cooccurrence is not ruled out on structural grounds. This fits with the actual chronology. As was shown in Sect. 3.1.3, the oldest attestations of pattern DD-a are from the $12^{\text {th }}$ century, and no other cases of double definiteness are attested before that. Double definiteness became an option only after reanalysis had taken place (given the time frame that I suggested in Sect. 5.1: $11^{\text {th }}$ century).

\subsection{Adjectival inflection and the lack of pattern (I)}

In Sect. 2.2, I briefly discussed the idea by Pfaff (2017) that the weak inflection is licensed iff the adjective is c-commanded by a definiteness feature in MI: 
(63)

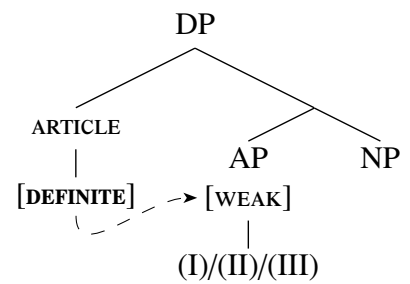

By assumption, the OI nominal article argued for above also carries some definiteness feature simply by virtue of "making the noun definite" (pre-theoretically speaking). On the current conception, it has scope only over the noun and nothing else. This entails, in particular, that it lacks the capacity to "make an adjective definite". If we equate making an adjective definite with licensing the weak inflection, the assumed badness of pattern (I), as evidenced by virtual non-attestation, can be captured by the same mechanism that governs the distribution of weak adjectives in MI: it follows from the fact that the OI nominal article is merged in such a low position that it does not c-command adnominal adjectives. ${ }^{42}$ This idea converges with the one suggested in Sects. 4.1/4.3, viz. that bare weak adjectives are not complete APs (notated below as "weakP"), but require a complementizer (= ART):

(64) a.

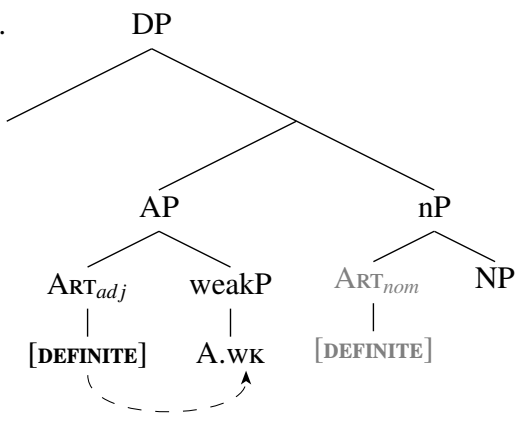

b.

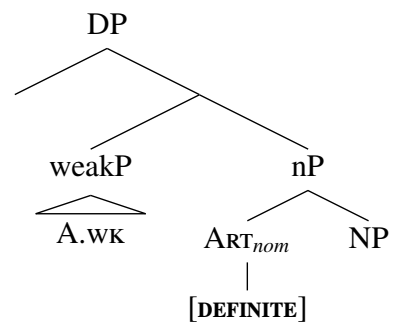

In (64-a), the weak inflection is licensed by the adjectival article/complementizer (and weakP is thus rendered a complete AP) - irrespective of whether the nominal article is present: DD-a, or not: pattern (II). On the other hand, (64-b), which is a pattern (I) constellation, is an illicit structure. It involves a bare weak adjective, i.e. an "incomplete" AP without its complementizer. Recall that other definite determiners like demonstratives are, at least potentially, alternative licensors of the weak inflection (Sect. 4.1). Now the nominal article does have a definiteness feature, so at least in principle, it could also be an alternative licensor of the weak inflection. However, by assumption, the nominal article is merged too low in the structure and its definiteness feature does not c-command the adjective - thus the the crucial structural pre-condition is violated. ${ }^{43}$

Hence, not only does the assumption of a distinct nominal article capture the occurrence of bare definite nouns and the possibility of double definiteness marking, a specific construal as a low $\mathrm{n}^{0}$ can account for the absence of pattern (I) in OI. 


\section{The bigger picture - some open issues}

The last two sections have argued for a distinction between an adjectival and a nominal article in OI. The former, which occurs as ART and occasionally as DEF, is a component of AP, whereas the latter, which manifests itself exclusively as DEF, is a low head in the nominal projection. In Sect. 2, on the other hand, I adopted a one-article analysis for MI, according to which ART and DEF are the same element at an abstract level of analysis, and occupy the same high position in the nominal projection. To the extent that both views can be maintained, we must assume that several developments have taken place during the 800 years under consideration, and, at the latest, during the $20^{\text {th }}$ century, these developments must have converged and previously distinct elements coincided categorially and structurally. Minimally, this process must comprise three developments: (i) coincidence of nominal article and postnominal adjectival article, (ii) movement of DEF "up the tree", (iii) reanalysis of ART from an adjectival complementizer in AP to a determiner in the xNP.

Development $(i)$ concerns the status of pattern (III-a). It may have started early on so as to get rid of a dual construal of DEF as either nominal or adjectival article, but it may also have lasted for some time. During the OI period, we find (III-a) and (III-b) alternations and especially certain minimal pairs as discussed in Sects. 3.1.2 and 5.2, which can have reinforced a construal of DEF as adjectival article, at least for a certain period. At some point, the motivation for that construal was no longer sufficiently strong or the motivation for a uniform construal was stronger, and, eventually, there was only one DEF with its ambiguity between adjectival and nominal article being neutralized. For development (ii), we have two assumed cornerstones: DEF as nominal article occupies a low $\mathrm{n}^{0}$ position in OI, but a high $\mathrm{D}^{0}$ position in MI. So the direction is straightforward in the long run: it has moved up the tree. ${ }^{44}$ In all likelihood, this went hand in hand with development (i).

Exploring these developments in detail is beyond the scope of this article, but I will have a look at the last one in Sect. 6.1 below. In Sect 6.2, I will briefly compare the status of DEF in Icelandic and NIScan.

\subsection{From adjectival complementizer to determiner}

Development (iii) follows from the construals of ART for OI and MI; if they are correct, this categorial and structural change must have taken place. It is more difficult to ascertain how it proceeded, but one factor that is likely to have influenced it considerably is the competition between ART and sá (see Sect. 3.2).

Now consider the following Old Danish example (early $11^{\text {th }}$ century):

(65) Óðinkár [...] pann dýra ok hinn dróttinfasta (DR 81)

Óðinkár sá valued and ART lord-loyal

'Óðinkárr [...] the valued and loyal to his lord'

This example illustrates, on the one hand, that sá occurs as an article element without demonstrative function, and on the other hand, that it can be coordinated with ART. Notably, coordination suggests that the two have the same categorial status, which, 
in turn, indicates that, in Old East Norse (= Old Swedish \& Old Danish), the distal demonstrative sá was originally developing into a genuine adjectival article, i.e. an adjectival complementizer in AP, on a par with (h)inn. Evidently, there was direct competion between sá and ART early on. Indeed, in Old East Norse, sá very soon became the dominant adjectival article while ART disappeared. As for the Modern NIScan languages, on the other hand, there is broad consensus that the adjectival article DET is an actual determiner (e.g. Vangsnes 1999; Julien 2005; Roehrs 2009). In other words, we must assume that $s a ́$ has undergone further developments on its way to modern DET in the NIScan languages (see Stroh-Wollin 2009, 2015a on (Old) Swedish) thus mirroring development (iii) for Icelandic ART.

Neither IcePaHC nor MÍM contain instances of sá A \& ART A coordination, and considering their categorial distinctness noted throughout Sect. 4, there do not seem to be any hints at a competition between sá and ART during the OI period. First indications of competition between the two can be found in the $16^{\text {th }}$ century. In Sect. 3.2.3, I suggested that the competition was an indication that sá was developing into an adjectival article, a replay of what had happened some centuries earlier in Old East Norse, cf. (65). That conclusion is not, however, inevitable; the development Icelandic sá underwent during the period under consideration probably was not towards a genuine adjectival article (= complementizer) like Viking period $(h)$ inn and Old East Norse sá. None of the criteria discussed in Sect. 4 - complementary distribution with strong adjectives, coordination, occurrence per adjective etc. - apply here. Rather it seems that sá was developing towards a determiner element more akin to modern DET. ${ }^{45}$ On this view, the competition between sá and ART also allows another interpretation: it was not was not exclusively about the development of sá, but also indicates that ART was developing from an adjectival complementizer into a determiner element.

\subsection{Icelandic and NIScan}

One difference between Icelandic and NIScan already pointed out is the survival vs. disappearance of hinn (ART). But there is another aspect that concerns the status of DEF. Many analyses of the Modern Scandinavian noun phrase (e.g. Vangsnes 1999; Julien 2005; Roehrs 2009) assume that the suffixed article occupies an $\mathrm{X}^{0}$ position below adjectives. If my analysis of the nominal article (Sect. 5) is on the right track, this would mean that DEF has remained in a low position in NIScan, but moved up the tree in Icelandic (= development (ii), see above).

But this actually raises an interesting question. Recall that Faarlund and Lohndal propose grammaticalization down the tree in order to capture the development of DEF from clitic to affix in Norwegian, see Sect. 1.3, while the present analysis suggests movement up the tree in Icelandic. Is this merely a different implementation that essentially captures the same development, viz. the well-known grammaticalization cline CLITIC > AFFIX, or does it indicate that the Icelandic development is qualitatively different? Faarlund (2009) makes a strong case that DEF is an inflectional suffix in Modern Norwegian and Swedish, but the arguments do not easily apply to Modern Icelandic. ${ }^{46}$ While DEF as such is a bound element, it is not simply a suffix. 
Unlike proper (inflectional or derivational) suffixes, for instance, it does not trigger

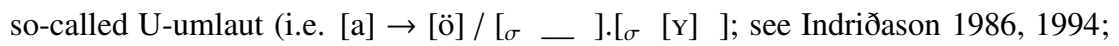
Pfaff 2007, 2009 on that point). Moreover, in contrast to a simple inflectional affix, Icelandic DEF can itself be segmented into stem + inflection:
a. barn $+u \mathrm{~m} \rightarrow$ börnum
child DAT.PL
inflectional suffix: U-umlaut

(67) a. hest -s -in -s (masc)

horse -GEN -DEF -GEN b. bar $+\mathrm{n} u \mathrm{~m} \rightarrow$ barnum

bar DEF

DEF: no U-umlaut

b. borg -ar -in -nar (fem)

city -GEN -DEF -GEN

Also the relationship between patterns (II) and (III) and adjective ordering in mixed (I+III) patterns (see Sect. 2.1) show that DEF participates in word order phenomena. Taken together, these points suggest that MI DEF, in spite of being a bound element, behaves more like an element of syntax ( clitic), not of morphology (inflectional affix). If this is correct, and given that the points illustrated by (66) and (67) have applied all along, it could simply be the case that, differently from Norwegian and Swedish, Icelandic DEF has never become an affix in the first place (which is also why I have refrained from talking about "grammaticalization up the tree").

\section{Conclusion}

In this article, I have outlined the development of the Icelandic article system from Proto-Norse to Modern Icelandic providing both an empirical and analytical perspective. While focusing on modified definite noun phrases, I have shown how these allow us to make inferences about the article elements involved. Even though several aspects, both diachronic and synchronic, have remained unaddressed, I believe that the new perspective brought up here sets the stage for further investigation.

A close examination of various noun phrase patterns has revealed several interesting states of affair that, to the best of my knowledge, have not received due attention in the literature. On the one hand, the MI standard pattern (I) only rose to relevance relatively recently, and double definiteness (DD-a) only disappeared even more recently. On the other hand, the double definiteness pattern DD-b and the "Danish" pattern DaN, two patterns etymologically corresponding to the standard patterns in other Scandinavian varieties, became prominent or even dominant between the $16^{\text {th }}$ and the $19^{\text {th }}$ centuries in Icelandic. The latter observation, I have interpreted as a competition between two adjectival articles hinn and sá. A similar, but not identical, development had taken place in Mainland Scandinavian some centuries earlier; the outcome, however, is quite different: in Icelandic, sá did not replace hinn.

In parallel, I have argued for a categorial distinction between an adjectival and a nominal article in Old Icelandic, where the former is a complementizer element allowing a weak adjective to function as an AP, and the latter a head in the nominal projection that has scope only over the noun. This distinction is not identical 
with a merely morpho-phonological differentiation between a freestanding and a suffixed/clitic article as two varieties of the same category. A number of observations made here - on the status of weakly inflected adjectives, complementary distribution and coordination of strong adjectives and the sequence ART A.wK, and noun phrases involving numerals - support the construal of the adjectival article as a narrow component of AP, rather than of xNP. On the other hand, assuming a distinct nominal article allows us to account for bare definite nouns, the virtual absence of pattern (I), and the various double definiteness constellations involving both ART and DEF. Moreover, with this distinction in place, we can now state that only the adjectival article, even if it occurs in suffixal form, requires the presence of an adjective, but not the nominal article, while analyses that assume one clitic article cannot correctly capture this dependency. Finally, in the few cases where a proper name occurs with a suffixal article, we can formulate a more precise description: only the adjectival article occurs suffixed to names, but not the nominal article.

For Modern Icelandic, I suggested, to the contrary, that free and suffixed articles actually are of the same category, in fact, the same element. To the extent that both perspectives are correct, this means that the diachronic development of two previously distinct elements must have resulted in their becoming one at some point. Going even one step further: since both originally started out from the same element (h)inn some time(s) during the Viking period - one way or another - the really big picture is that one element, gives rise to two distinct elements, but a thousand years or so later, these two elements coincide once more as two manifestations of one element.

\section{ACKNOWLEDGMENTS}

Research for this article was supported by the project Constraints on syntactic variation: Early Germanic noun phrases (Norwegian Research Council, grant no. 261847). I would like to thank Kersti Börjars and Ulla Stroh-Wollin for comments and discussion on various aspects. Moreover, I would like thank three anonymous reviewers for constructive criticism and helpful comments, which helped to improve the quality of this article considerably. Any remaining shortcomings are mine.

\section{ENDNOTES}

1. Glosses used here: DEF - suffixed definite article; ART - freestanding (adjectival) article in Icelandic and Old Norse; DET - freestanding (adjectival) article in modern Scandinavian (modulo Icelandic); sá - distal demonstrative sá in Old Norse and Icelandic; wK - weak adjectival inflection; STR - strong adjectival inflection; UNDEC - undecidable whether strong or weak (this goes especially for adjectives in the comparative form); suPL - superlative; Poss -3 . pers. reflexive possessive.

Adjectival inflection will only be glossed when strong and weak inflection are contrasted, especially, in Sects. 2 and 4. If not glossed or commented upon, the adjectives under discussion are weakly inflected.

2. The label "xNP" denotes an unspecified nominal extended projection (i.e. NP, nP or DP 
etc.), used when the precise categorial status is irrelevant to the point at issue.

3. sá (accusative forms): pann/pan $\rightarrow$ den, tann (masc/fem); pat/pat $\rightarrow$ det, tað (neut).

4. The Icelandic textual transmission starts in the $12^{\text {th }}$ century, and for the purpose of this article, when talking about Old Icelandic (OI), I will loosely refer to the period from the $12^{\text {th }}$ to the $15^{\text {th }}$ century. Since I will also be looking at individual centuries, this terminology is largely secondary. It is relevant, however, insofar as this article is about Icelandic; in the literature, the terms Old Icelandic and Old Norse are often used virtually synonymously. Some claims about OI made here will certainly apply to Old (West) Norse more generally, but unless indicated otherwise, I am not committed to such extensions.

5. Wallenberg et al. (2011)

6. For instance hinum hasta höfuðsm $\$$ \$ ið (ID 1902.FOSSAR.NAR-FIC,.548); here, the sequence "ið" is annotated as suffixed article, while it actually is part of the noun $h \ddot{o}$ fuðsmið(ur).

7. http://mim.hi.is/index.php?corpus=for

8. When citing an example from MíM, only the title of the respective text is given; when citing a noun phrase from IcePaHC, the year and text signature are given:

(i) a. priðja dag -inn

third day -DEF

(Sturlunga saga) $\Leftarrow$ MÍM b. vetur -inn næsta

winter -DEF next

(1250 sturlunga) $\Leftarrow \mathrm{IcePaHC}$

Note that this is not a philological study. I entirely rely on the (print) editions upon which MÍM and IcePaHC are based, which also means that examples will be given in Modern Icelandic orthography.

9. http://www.nordiska.uu.se/forskn/samnord.htm

10. These numbers are about the items as such, overlaps are possible. After all, noun phrases comprising ART will also contain an adjective, and thus are also counted under adj etc. The discussion to come does not hinge on these numbers, though.

11. For a detailed discussion of the various patterns and their syntactic and semantic properties, see Pfaff (2015, 2016, 2017); see also Ingason (2016, 115-134).

12. Notice that the normalized text in (9) renders (h)inn as a separate word. But in this particular instance, the Runic inscription itself - the rune carver put an an " $x$ " between words (here rendered as asterisk) - suggests that $N+(h)$ inn be construed as one (phonological) word ("mirkit" = merkit, or merkið in modern spelling).

13. But see Stroh-Wollin (2014) who suggests that a demonstrative reading of ( $h$ )inn for this case cannot be ruled out (= 'this soul').

14. For a dissenting view, viz. that they are distinct elements, see e.g. Rögnvaldsson (1990); Vangsnes (1999), both of which suggest that ART is a demonstrative.

15. Older accounts like Magnússon and Sigurðsson assume that the underlying article form is hinn (= ART), which loses the $h$ in the course of cliticization. In contrast, Pfaff (2015); Ingason (2016) assume that there are two morphemes: $h(i)-+-i n n$, where -inn is the actual article component common to both articles. The morpheme $h(i)$ - is merged if the nominal constituent does not move before the article thus fusing with -inn and producing ART.

16. Usually, it is claimed is that the free article imposes a non-restrictive reading on the adjective, e.g. Vangsnes (1999, 130); Thráinsson (1995, 98), Thráinsson (2007, 4 and 89, fn. 2); Roehrs (2009); see Pfaff (2015, 96-115) for a more detailed discussion.

17. The label $\alpha \mathrm{P}$ is adopted from Julien (2005) and designates a functional projection hosting an adjectival constituent in its specifier position; similarly for $\beta \mathrm{P}$ in (23).

18. For space reasons, I cannot go into all arguments and details of this analysis. An anonymous reviewer comments on this paragraph: "the argument [...] strikes me as potentially circular. What prevents a strong adjective and a weak adjective from co-occurring so ASTR hinn A-wK N (I assume they don't)?" Answer: actually they do cooccur. In fact, this 
is a crucial argument in Pfaff's analysis; certain strongly inflected modifiers that otherwise occur in pattern (IV) can (and do) precede hinn + A-wK.

19. This construal is suggested by the IcePaHC annotation.

20. NB: the comparative inflection does not formally distinguish between weak and strong endings (= undecidable, see fn. 1). So strictly speaking, it is not possible to determine whether (25-a)/ (25-d)/(25-f) and (26-a)/(26-f) are really instances of pattern (I) or (IV).

21. This label captures a small class of functional adjectives that do not have a positive form, but only occur in the comparative and/or superlative form, e.g. ytri / ystur - "outer / outmost"; efri / efstur - "upper / up-most, top-most"; fyrri / fyrstur - "earlier, former, previous / first"; vinstri / hagri - "left / right", etc.

22. With one qualification: only noun phrases with a lexical noun were counted, while examples with proper names, like Atli hinn svarti "Atli the Black" or "Salómon hinn spaki "Solomon the Wise" were dismissed.

23. This pattern is not examined here and does not show up in the tables. Mím contains 38 instances, IcePaHC 13 ( 11 of which are from before the $17^{\text {th }}$ century, one example is from 1861 (orrusta) and one from 1907 (leysing)). More specifically, in MíM, there are ten instances of the sequence N-DEF HINN, 27 instances of N-DEF DEM HINN, and one instance of $\mathrm{N}$-DEF POSS HINN. In IcePaHC, there are four instances of N-DEF DEM HINN (all prior to the $15^{\text {th }}$ century), and nine instances of the sequence N-DEF HINN.

24. The last example in IcePaHC is from 1907 (leysing).

25. The first complete Icelandic bible translation; see http://biblian.is/gudbrandsbiblia/

26. https://is.wikisource.org/wiki/N\%C3\%BDja_testamenti_Odds_Gottsk\%C3\%A1lkssonar Form\%C3\%A1li

27. In this context, the dependency on genre or even author should be examined more carefully. A first glimpse at the texts in IcePaHC suggests that DAN, or sá, tends to be more prominent in religious texts often scoring more than $90 \%$ out of the pattern total, e.g. 1593 eintal (total: 93; DD-b: 7, DAN: 82), 1611 okur (total: 60; DD-b: 3, DAN: 56), 1630 gerhard (total: 65; DD-b: 25, DAN: 38), whereas it seems to be less prominent in some other narrative texts, e.g. 1650 illugi (total: 26; (I): 3, (II): 16, DD-a: 2, DD-b: 0, DAN: 2). A detailed examination of the individual texts is outside the scope of this article. Nonetheless the context of the reformation is highly suggestive; since religion / religious ideas were, in fact, imported from Denmark, it seems likely that religious texts were especially susceptible to Danish influence.

28. Notice also that, according to table 4, pattern (II) reaches a low point in terms of frequency precisely when DAN reaches its peak.

29. I have not examined each individual example for their semantic properties. The following example of an anaphoric noun phrase illustrates at least a certain uncertainty between demonstrative / article interpretation as indicated in the paraphrase:

(i) [...] ekkju - sem öngvan hlut átti til [...] pá kom sú fátæka kvinna -n heim widow who no thing owned then came sá poor woman-DEF home '[a widow who owned nothing $]_{1} \quad[\ldots]$ then [that / the poor woman $]_{1}$ came home' (1525.GEORGIUS.NAR-REL,.403)

30. As an aside, sá is normally used as a demonstrative in Modern Icelandic; remnants of its function as an adjectival article can be found with elliptic noun phrases:

(i) sá stóri sá big 'the big one'

31. Such adjectives often behave differently from "regular", i.e. descriptive adjectives. In Sect. 3.1.1, it was shown that the majority of early pattern (I) attestations involve functional adjectives. Possibly, this can be seen as a consequence of the fact that they them- 
selves have determiner-like properties/functions; see also fn. 42. Also in modern double definiteness languages, these adjectives behave exceptionally in that they freely occur without the otherwise obligatory pre-adjectival article, cf. Delsing (1993); Dahl (2015).

32. A different way of putting this is that it is specifically ART and the strong inflection that are in complementary distribution, which is strongly reminiscent of Leu (2008).

33. In many such cases, the adjective can be construed as a SL predicate (angry, glad, cheerful, furious ...), but this cannot be the correct generalization insofar as IL predicates are also found occasionally (fine, brave; cf. (44)). The deeper generalization seems to be that the adjective involved in this construction must be predicative (i.e. of type $<\mathrm{e}, \mathrm{t}>$ ).

34. Even more so during the Viking period, see Perridon (1996); see also Delsing (1994); Stroh-Wollin and Simke (2014) on Old Swedish.

35. When in immediate adjacency, demonstratives precede possessives, while ART can only follow a possessive.

36. In MÍM, I have so far found 28 instances of [ART A.wK] \& [ART A.wK], but also two instances of [ART A.WK] \& [A.WK] (in both cases of the latter, both adjectives are superlatives; see fns. 31, 42). Adjectival coordination in OI is more diverse and should be further investigated. Coordination of two strong adjectives constitues the most common type; beside that, we also find [A.sTR] \& [ART A.wK], and [ART A.wK] \& [A.sTR], see e.g. (44). I haven't found any instances of a strong adjective and a bare weak adjective being coordinated.

37. Faarlund $(2007,2009)$ proposes a recursive DP structure where sá is the head of the higher DP expressing deixis and uniqueness and ART the head of the lower DP (= RP) encoding specificity. He comments on ex. (51-b): "[t]his difference in the referential properties and semantic function of the two determiners is also seen by the fact that when two adjectives are used to modify the same noun, the article is repeated but not the demonstrative" (Faarlund 2009, 628). Strictly speaking, of course, the two adjectives do not modify the same noun on this analysis, insofar as it entails RP coordination with an elliptic noun in the first conjunct. "Genuine" adjectival coordination, according to this analysis, does not allow repetition of ART, which is the head of RP, and would only involve two weak adjectives: ART A.wK \& A.wK. Compare the respective construals:

(i) Coordination according to Faarlund (2007, 2009):

a. RP coordination: $\quad\left[{ }_{D P}\right.$ sá $\left[{ }_{R P}\left[{ }_{R P}\right.\right.$ hinn A.wK $\left.\varnothing\right] \&\left[{ }_{R P}\right.$ hinn A.wK N $\left.]\right]$

b. Adjectival coordination: $\quad\left[{ }_{D P}\right.$ sá $\left[{ }_{R P} \operatorname{hinn}\left[{ }_{A P}\left[{ }_{A P}\right.\right.\right.$ A.wK $] \&\left[{ }_{A P}\right.$ A.wK $\left.]\right]$ N $]$

In other words, Faarlund's analysis predicts a structural difference depending on whether the second (weak) adjective is preceded by ART, or not. Moreover, it entails that weak adjectives by themselves constitute "complete" APs. In contrast, on the present analysis, which assumes that weak adjectives are not "complete" APs, both constellations instantiate (the same kind of) adjectival coordination with the proviso that, very exceptionally, ART may be zero in the second conjunct (see fn. 36):

(ii) Present analysis:

a. Adjectival coordination: $\quad\left[D P\right.$ sá $\left[{ }_{A P}\left[{ }_{A P}\right.\right.$ hinn A.wK $] \&\left[{ }_{A P}(\right.$ hinn $)$ A.wK $\left.]\right]$ N $]$

38. Thanks to an anonymous reviewer for suggesting this test.

39. Incidentally, numerals potentially also intervene between DEF and postnominal adjective (see also Pfaff 2015, 41,95):

(i) myndir -nar prjár frægu

(cf. Harðarson 2014)

pictures DEF three famous.wK

40. This epithetic function of ART A.wK was in use throughout the OI period and beyond. 
41. Again, this idea is not really new; informally, it is expressed for instance by Nygaard (1906, 48): "Den foranstillede artikel er adjektivisk d.e. sættes kun til substantiv med tilføiet adjektiv eller til et substantivisk brugt adjektiv" ("The preposed article is adjectival; it is used with a substantive only when accompanied by an adjective or with a substantively used adjective [i.e. a nominalized adjective]", translation mine).

42. In Sect. 3.1.1, it was shown that most adjectives occurring in the (few) attested examples are functional adjectives, see fn. 21, and those have in particular in common a close conceptual affinity with uniqueness, a core component of definiteness. In this sense, they can be said to make their own contribution to (semantic) definiteness, which seems to be a facilitating factor. Thus the really deviant scenario is instantiated by five examples of "regular" descriptive adjectives occurring in pattern (I); see also fn. 31.

43. As a conjecture to be examined further: possibly, the oldest attestations of pattern (I) can be construed as "defective" DD-a where ART is not spelled out.

44. NB: This is the precise opposite of Lohndal's "Grammaticalization down the tree" (from $\mathrm{D}^{0}$ to $\left.\mathrm{n}^{0}\right)$, see Sect. 1.3.

45. Here it would be particularly revealing to examine the status of Danish sá/DET during the relevant period more carefully, given the assumption that the Icelandic development was influenced by Danish.

46. Conversely, his arguments that DEF is a clitic in OI do apply to MI.

\section{REFERENCES}

Adrados, Francisco Rodriguez, Alberto Bernabé, and Julia Mendoza. 2016. Manual of IndoEuropean linguistics : Vol. 2 : Nominal and verbal morphology. Leuven: Peeters.

Börjars, Kersti, and Pauline Harries. 2008. The clitic-affix distinction, historical change, and Scandinavian bound definiteness marking. Journal of Germanic Linguistics 20 (4): 289350 .

Börjars, Kersti, and John Payne. 2016. Adjectival definiteness marking and noun-phrase internal functions. University of Manchester, HEADLEX, 25 July 2016.

Börjars, Kersti, Pauline Harries, and Nigel Vincent. 2016. Growing syntax: The development of a DP in North Germanic. Language 92 (1): 1-37.

Cinque, Guglielmo. 2005. Deriving Greenberg's Universal 20 and its Exceptions. Linguistic Inquiry 36 (3): 315-332.

Curme, George O. 1910. The origin and growth of the adjective declension in Germanic. The Journal of English and Germanic Philology 9 (4): 439-482.

Dahl, Östen. 2015. Grammaticalization in the North: Noun phrase morphosyntax in Scandinavian vernaculars, Vol. 6. Language Science Press.

Delbrück, Berthold. 1916. Der altisländische Artikel. Germanische Syntax III. Leipzig: Teubner.

Delsing, Lars-Olof. 1993. The internal structure of noun phrases in the Scandinavian languages. PhD diss, University of Lund.

Delsing, Lars-Olof. 1994. Hans siukt ben - Om starka och svaga adjektiv i fornsvenskan. In Språkbruk, grammatik och språkförändring: En festskrift til Ulf Teleman, eds. Nils Jörgensen, Christer Platzack, and Jan Svensson, 99-108. University of Lund: Department of Scandinavian Languages.

Faarlund, Jan Terje. 2004. The Syntax of Old Norse. Oxford: Oxford University Press.

Faarlund, Jan Terje. 2007. From clitic to affix: The Norwegian definite article. Working Papers in Scandinavian Syntax 79: 21-46.

Faarlund, Jan Terje. 2009. On the history of definiteness marking in Scandinavian. Journal of Linguistics 45 (3): 617-639.

Harðarson, Gísli Rúnar. 2014. The structure of noun phrases an synthetic compounds. Abstract 
$42 \mid$ ALEXANDER PFAFF

submitted to the workshop "The North Germanic Noun Phrase" (held in Troms $\varnothing$, May 22/23, 2014).

Harðarson, Gísli Rúnar. 2016. Cycling through grammar: On compounds, noun phrases and domains. PhD diss, University of Connecticut.

Heinrichs, Heinrich Matthias. 1954. Studien zum bestimmten artikel in den germanischen Sprachen. Giessen: W. Schmitz.

Himmelmann, Nikolaus P. 1997. Deiktikon, Artikel, Nominalphrase: Zur Emergenz syntaktischer Struktur. Max Niemeyer Verlag.

Indriðason, Thórsteinn. 1986. Staða greinis í íslensku málkerfi. BA thesis, University of Iceland.

Indriðason, Thórsteinn. 1994. Regluvirkni í orðasafni og utan pess. Um lexíkalska hljóðkerfisfræði í íslensku. Master's thesis, University of Iceland, Reykjavík.

Ingason, Anton Karl. 2016. Realizing morphemes in the Icelandic noun phrase. PhD diss, University of Pennsylvania.

Julien, Marit. 2005. Nominal phrases from a Scandinavian perspective. Amsterdam: John Benjamins.

Kovari, Geoffrey. 1984. Studien zum germanischen Artikel: Entstehung und Verwendung des Artikels im Gotischen. Wien: Halosar.

Laake, Signe. 2007. Nomenfrasen i norrønt og norsk. En diakron analyse. Master's thesis, University of Oslo.

Leu, Thomas. 2008. The internal syntax of determiners. PhD diss, New York University.

Lohndal, Terje. 2007. On the structure and development of nominal phrases in Norwegian. In Nominal determination, eds. Werner Abraham, Elisabeth Leiss, and Elisabeth Stark, 287-310. Amsterdam: John Benjamins.

Lundeby, Einar. 1965. Overbestemt substantiv i norsk: og andre nordiske språk: mit einer deutschen zusammenfassung. Universitetsforlaget.

Magnússon, Friðrík. 1984. Um innri gerð nafnliða í íslensku. Íslenskt mál 6: 81-111.

Nygaard, Marius. 1906. Norrøn syntax. Oslo: H. Aschehoug \& Company (W. Nygaard). [2nd, unrevised edition, 1966].

Osthoff, Hermann. 1876. Zur Geschichte des schwachen deutschen Adjectivums: eine sprachwissenschaftliche Untersuchung, Vol. 2. Jena: Costenoble.

Perridon, Harry. 1996. Noun phrases in Runic Swedish. In The Nordic Languages and Modern Linguistics, vol. 9: Proceedings of The Ninth International Conference of Nordic and General Linguistics, ed. Kjartan G. Ottóson et al., 248-61. Oslo: Novus Forlag.

Perridon, Harry, and Petra Sleeman. 2011. The noun phrase in Germanic and Romance. In The noun phrase in Romance and Germanic, eds. Harry Perridon and Petra Sleeman, 1-21. Amsterdam: John Benjamins.

Pfaff, Alexander. 2007. Tvennt en samt eitt. Ákveðinn greinir í íslensku. BA thesis, University of Iceland.

Pfaff, Alexander. 2009. Structural Relations between Free and Suffixed Articles in Icelandic. Master's thesis, University of Tübingen.

Pfaff, Alexander. 2014. Inside and outside - before and after. Weak and strong adjectives in Icelandic. In Adjectives in Germanic and Romance, eds. Petra Sleeman, Freek Van de Velde, and Harry Perridon, 217-244. Amsterdam: John Benjamins.

Pfaff, Alexander. 2015. Adjectival and Genitival Modification in Definite Noun Phrases in Icelandic - A Tale of Outsiders and Inside Jobs. PhD diss, University of Troms $\varnothing$.

Pfaff, Alexander. 2016. Icelandic articles and anaphora - the free article can be strong! Ms., available at: http://lingbuzz.auf.net/lingbuzz/003371

Pfaff, Alexander. 2017. Adjectival inflection as diagnostic for structural position - Inside and outside the Icelandic definiteness domain. Journal of Comparative Germanic Linguistics 20 (3): 283-322.

Pokorny, Julius. 1959. Indogermanisches etymologisches Wörterbuch [Indo-European Etymological Dictionary]. Bern: Francke. 
Ratkus, Arturas. 2011. The adjective inflection in Gothic and early Germanic: Structure and development. PhD diss, University of Cambridge.

Rehn, Alexandra. 2018. Adjectives and the Syntax of German(ic) DPs - a diachronic and dialectal Perspective. PhD diss, University of Konstanz.

Rießler, Michael. 2016. Adjective attribution. Berlin: Language Science Press.

Ringe, Donald. 2006. A Linguistic History of English: Volume I, From Proto-Indo-European to Proto-Germanic. Oxford Scholarship Online.

Roehrs, Dorian. 2009. Demonstratives and definite articles as nominal auxiliaries. Amsterdam / Philadelphia: John Benjamins.

Roehrs, Dorian, and Christopher D. Sapp. 2004. The rise of the suffixal article in the early North Germanic DP. In Proceedings of WECOL 2004, eds. Michal Temkin Martínez, Asier Alcázar, and Roberto Mayoral Hernández, 290-301. Department of Linguistics, California State University.

Rögnvaldsson, Eiríkur. 1990. Íslensk orðhlutafraði. Kennslukver handa nemendum á háskólastigi, 4th edn. Reykjavík: Málvísindastofnun Háskóla Íslands.

Sigurðsson, Halldór Ármann. 1993. The structure of the Icelandic NP. Studia Linguistica 47 (2): 177-197.

Skrzypek, Dominika. 2009. The formation of the definite article in the Nordic languages. Lingua Posnaniensis 51: 65-76.

Skrzypek, Dominika. 2010. Between a demonstrative and an article. The status of -in in Old Swedish. Folia Scandinavica 11: 145-162.

Skrzypek, Dominika. 2012. Grammaticalization of (in)definiteness in Swedish. Wydawnictwo Naukowe UAM.

Stroh-Wollin, Ulla. 2009. On the development of definiteness markers in Scandinavian. Working Papers in Scandinavian Syntax 83: 1-25.

Stroh-Wollin, Ulla. 2012. U 169 Björkeby: A Daughter without a Name? Futhark: International Journal of Runic Studies 2: 193-200.

Stroh-Wollin, Ulla. 2014. Hinn, inn eller enn? Om uppkomsten av det nordiska bestämdhetssuffixet. In Studier i svensk språkhistoria 12. Variation och förändring. [Stockholm Studies in Scandinavian Philology. New Series 60.], eds. M. Bylin, C. Falk, and T. Riad, 229-239. Stockholm University.

Stroh-Wollin, Ulla. 2015a. Från gammal man till den gamle mannen: Definitmarkering i fornsvenska nominalfraser med adjektivattribut. Arkiv för nordisk filologi 130: 101-138.

Stroh-Wollin, Ulla. 2015b. Understanding the gradual development of definiteness marking: the case of Swedish. Working Papers in Scandinavian Syntax 95: 11-32.

Stroh-Wollin, Ulla. 2016. The emergence of definiteness marking in Scandinavian - new answers to old questions. Arkiv för nordisk filologi 131: 129-169.

Stroh-Wollin, Ulla, and Rico Simke. 2014. Strong and weak adjectives in Old Swedish. In Adjectives in Germanic and Romance, eds. Petra Sleeman, Freek Van de Velde, and Harry Perridon, 95-112. Amsterdam: John Benjamins.

Thráinsson, Höskuldur. 1995. Handbók um málfrææði. Reykjavík: Námsgagnastofnun.

Thráinsson, Höskuldur. 2007. The syntax of Icelandic. Cambridge: Cambridge University Press.

Vangsnes, Øystein Alexander. 1999. 'Identification' and the role of morphology in the Scandinavian noun phrase. Ms., University of Bergen.

Viti, Carlotta. 2015. Variation und Wandel in der Syntax der alten indogermanischen Sprachen. Tübingen: Narr.

Wallenberg, Joel C, Anton Karl Ingason, Einar Freyr Sigurðsson, and Eiríkur Rögnvaldsson. 2011. Icelandic parsed historical corpus (IcePaHC). Version 0.9. (http://www.linguist.is/icelandic_treebank).

Werner, Otmar. 1984. Morphologische Entwicklungen in den Germanischen Sprachen. In Das Germanische und die Rekonstruktion der indogermanischen Grundsprache, eds. Jürgen Untermann and Bela Brogyanyi. Amsterdam: John Benjamin. 